\title{
Article \\ Performance of Hybrid Wheat Cultivars Facing Deficit Irrigation under Semi-Arid Climate in Pakistan
}

\author{
Muhammad Mehran Anjum ${ }^{1}$, Muhammad Arif ${ }^{1}$, Muhammad Riaz ${ }^{2, *}$, Kashif Akhtar $^{3} \mathbb{D}$, Sheng Quan Zhang ${ }^{4, *}$ \\ and Chang Ping Zhao ${ }^{4, *}$
}

1 Department of Agronomy, The University of Agriculture, Peshawar 25000, Pakistan; mehrananjum@aup.edu.pk (M.M.A.); marifkhan75@aup.edu.pk (M.A.)

2 Department of Environmental Sciences \& Engineering, Government College University, Faisalabad 38000, Pakistan

3 State Key Laboratory for Conservation and Utilization of Subtropical Agro-Bio-Resources, College of Life Science and Technology, Guangxi University, Nanning 530004, China; kashif@zju.edu.cn

4 Beijing Engineering Research Center for Hybrid Wheat (BERCHW), Beijing Academy of Agricultural and Forestry Sciences (BAAFS), No. 9 Shuguang Garden Middle Road of Banjing, Beijing 100097, China

* Correspondence: muhammad.riaz@gcuf.edu.pk (M.R.); zsq8200@126.com (S.Q.Z.); cp_zhao@vip.sohu.com (C.P.Z.)

check for updates

Citation: Anjum, M.M.; Arif, M.; Riaz, M.; Akhtar, K.; Zhang, S.Q.; Zhao, C.P. Performance of Hybrid Wheat Cultivars Facing Deficit Irrigation under Semi-Arid Climate in Pakistan. Agronomy 2021, 11, 1976. https://doi.org/10.3390/ agronomy 11101976

Academic Editor: Jose

Manuel Gonçalves

Received: 27 July 2021

Accepted: 25 September 2021

Published: 30 September 2021

Publisher's Note: MDPI stays neutral with regard to jurisdictional claims in published maps and institutional affiliations.

Copyright: (c) 2021 by the authors. Licensee MDPI, Basel, Switzerland. This article is an open access article distributed under the terms and conditions of the Creative Commons Attribution (CC BY) license (https:// creativecommons.org/licenses/by/ $4.0 /)$.

\begin{abstract}
Predicted decrease in water availability for crop production and uncertainty in climatic conditions require devising the irrigation strategies to increase water use efficiency (WUE) for sustainable crop production. The development of crop cultivars with higher WUE is a pre-requisite for such strategies, particularly in developing countries, including Pakistan, who face stern food security challenges. A two-year field study was conducted following a split-plot randomized complete block design to understand the effects of wheat cultivars (hybrid cultivars, 18A-1 and 18A-2, and local cultivar Ghaneemat IBGE-2016), sowing dates (15th November, 30th November, and 15th December), and irrigation regimes [I (103 mm), II (175 mm), III (254 mm), and IV (330 mm)] at four different growth stages of tillering, booting, anthesis and grain filling on wheat productivity, biomass production and grain yield, and crop-water relations. Early sown hybrid cultivars 18A-1 and 18A-2 showed significantly higher biological and grain yields compared to the local cultivar (59\% and 69\% higher than the local cultivar). Trends in biomass production and grain yield were also similar at later sowing dates of 30th November and 15th December. However, biological and grain yields decreased with delay in sowing for each cultivar. The data also revealed that hybrid cultivars were better suited to deficient irrigation and generally produced significantly higher biological and grain yields under each moisture regime. Cultivars, sowing dates, and irrigation regime differed significantly for their effects on the Soil Plant Analysis Development (SPAD) values, chlorophyll a and $\mathrm{b}$ contents but not for carotenoids. Sowing dates and irrigation regimes had significant effects on relative water content (RWC), water saturation deficit (WSD), water uptake capacity (WUC), and water retention capacity (WRC); however, only WUC varied significantly between the cultivars. The phenological data show that hybrid cultivars took more days to maturity and grain filling than the local cultivar, and days decreased with delayed sowing. The biological and grain yields show significant positive correlations with SPAD values $(p<0.001)$ and days to maturity $(p<0.001)$. Our study shows that hybrid wheat cultivars can be opted for higher biomass production and grain yields under deficit irrigation scenarios of semi-arid climatic conditions in Pakistan. Moreover, the hybrid wheat cultivars can perform better than the indigenous cultivar even for delayed sowing dates of 30th November and 15th December.
\end{abstract}

Keywords: hybrid wheat cultivar; irrigation regime; sowing dates; crop-water relations; grain yield 


\section{Introduction}

Global climate change is predicted to enhance the frequency and occurrence of dry weather conditions with concomitant adverse effects on cereal production and food security [1-3]. Fresh water availability is decreasing and has become a serious ecological factor that limits agricultural production [4]. The adverse effects of fresh water scarcity on crops coupled with the irrigation costs, restricted water resources, and insufficient irrigation facilities have compelled the farmers to use irrigation water more efficiently $[5,6]$. Appropriate irrigation strategies are, therefore, required to increase water use efficiency (WUE) for sustainable crop production [7]. Moreover, the fundamental approach for sustainable cereal production under semi-arid climatic conditions is to use irrigation water efficiently by developing water-saving farming strategies and improving WUE $[2,8]$. In cereals, adequate water availability after anthesis gives extra time to translocate carbohydrates to grains and, hence, increase photosynthetic efficiency and grain yields $[9,10]$. Current fresh water scarcity is threatening winter wheat productivity, and this trend is anticipated to increase many-folds in the future. Therefore, the farmers have to deal with fresh water scarcity by adopting water management techniques for sustaining winter wheat productivity and grain yield. Resultantly, deficit irrigation is considered an effective measure to increase irrigation water productivity in arid and semi-arid regions, including Pakistan [11-13].

The strategy of applying irrigation during drought-sensitive growth stages of crops is called deficit irrigation, and it has been successfully used to improve crop yields such as rice [14], corn [15], forages [16], oilseed rape [17], and soybean [18]. However, many studies have also found a substantial reduction in grain yield of several crops including winter wheat under deficit irrigation practices. The wheat yield can be optimized when the crop is subjected to deficit irrigation up to $75 \%$ of soil water deficit [19]. Water use efficiency is the ratio of dry matter production to the total amount of water applied. The improvement in biomass production per unit of water used showed an increase in WUE [20]. Furthermore, WUE is an imperative attribute to measure the drought tolerance of crops [21]. Similarly, Li et al. [22] also found a significant increase in winter wheat grain yield and WUE under deficit irrigation. Recent studies have further suggested that deficient irrigation has the potential to increase crop production by enhancing WUE in semi-arid regions [23]. Moreover, deficit and supplementary irrigation scheduling have become core strategies to deal with climatic variability [24].

Sowing time is an important agronomic factor determining the production of high yielding cereal crops because it influences the duration and timing of reproductive and vegetative growth stages [25]. Late-planted wheat grows slowly due to low temperature and results in poor germination, fewer crop stands, and low grain quality. Delay in sowing beyond recommended sowing dates reduces the number of growing days and yield of wheat because of exposure to higher temperatures at later growth stages towards maturity $[26,27]$. During the growth cycle, crop varieties vary in their growth and input requirements based on their genotypic characteristics and suitability to different environmental conditions. About 9.25 million ha of wheat is cultivated in Pakistan with the production of 25.5 million tons, while in the province of Khyber Pakhtunkhwa (KP), it was cultivated on about 0.75 million ha with an estimated production of about 1.4 million tons [28]. In the KP province, wheat is grown on more than $52 \%$ cultivated area as a rainfed crop with low average yields due to lack of appropriate wheat cultivars suitable for the local climatic conditions and sowing time in winter [29]. In given agro-climatic conditions, the growth and development of wheat cultivars differ, and, therefore, identification of cultivars having specific recommended sowing dates is critical for optimum crop yields. Considering the significance of appropriate variety for the rainfed/irrigated regions of Pakistan and particularly in the KP province, selection of the drought-resistant and/or -tolerant wheat cultivars is a pre-requisite for higher crop yields under deficient moisture conditions. Under such scenarios, drought-tolerant or -resistant varieties can survive better [30,31]. Hybrid crop cultivars have been widely adopted to improve crop production and yield under various environmental stresses to fit desirable agronomic conditions such 
as deficit irrigation and droughts [32]. Despite earlier failures in developing hybrid wheat cultivars, they have been marketed in Europe and the USA in the 1990s, whereas efforts on hybrid wheat in China started during the late 1980s; however, work on hybrid wheat in India and Pakistan is still at an initial stage of development [33].

Despite being the eighth largest wheat growing country in the world, Pakistan is ranked at the 40th place for the average yield, and the historical data suggest that the average wheat yield has not improved much over the last two decades [34,35]. Therefore, hybrid wheat cultivars can improve wheat production by overcoming various biotic and abiotic stresses to close the yield gaps and ensure food security [36,37]. We hypothesized that hybrid wheat cultivars are a better option for higher crop yields under deficit irrigation due to better phenological traits, crop-water relationships, and higher WUE. The objectives of this pioneer two-year field study under the semi-arid climatic conditions in Pakistan were to:

(1) Investigate the performance of two hybrid (18A-A \& 18A-2) and a local (Ghaneemat IBGE 2016) wheat cultivars grown under four deficit irrigation water regimes and sown at three dates of 15 November, 30 November, and 15 December;

(2) Understand the relationships between phenological traits, crop-water relationships, and biological and grain yields of hybrid and local wheat cultivars.

\section{Materials and Methods}

\subsection{Study Site Characteristics}

A two-year field study was conducted at the Agronomy Research Farm, The University of Agriculture Peshawar Pakistan (34.0206 N, 71.4815 E). The site has warm-hot, semiarid, sub-tropical, and continental climatic conditions, having a mean cumulative rainfall of $360 \mathrm{~mm}$ and being situated at $331 \mathrm{~m}$ above sea level. The average winter rainfall is higher than that of the summer. From May to September in Summer, the mean maximum and minimum temperature are $40{ }^{\circ} \mathrm{C}$ and $25^{\circ} \mathrm{C}$, respectively (Figure 1), whereas from December to March in winter, the mean minimum and maximum temperature are $4.0^{\circ} \mathrm{C}$ and $18.4{ }^{\circ} \mathrm{C}$, respectively. The historical data of the last two decades suggest that the mean annual maximum and minimum temperature were $26.3^{\circ} \mathrm{C}$ and $12.5^{\circ} \mathrm{C}$, respectively, whereas the mean annual rainfall was $66.2 \mathrm{~mm}$ in the study site region. The soil at the study site is alkaline calcareous silty clay loam with low total organic $C$ and $N$ contents of $8.21 \mathrm{~g} \mathrm{~kg}^{-1}$ and $0.52 \mathrm{~g} \mathrm{~kg}^{-1}$, respectively (Table 1). The soil is known to have low native fertility under the prevalence of semi-arid climatic conditions.

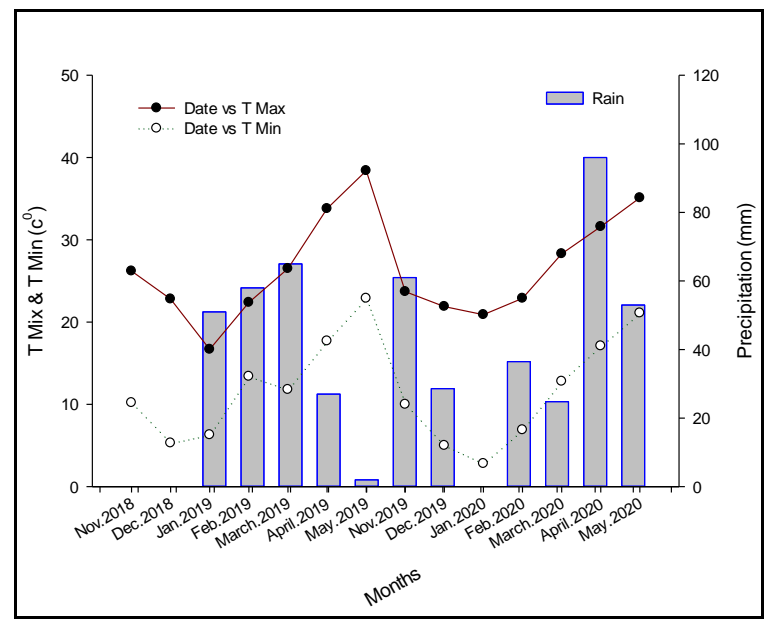

Figure 1. Average means monthly weather data of two years (2018-2019 and 2019-2020) experimental location for the crop growth season. Nov = November, Dec = December, Jan = January, Feb = February. (Source: Peshawar Metrological Department). 
Table 1. Physico-chemical properties of soil at the experimental site.

\begin{tabular}{cc}
\hline Properties & Values \\
\hline $\mathrm{pH}\left(\mathrm{H}_{2} \mathrm{O}\right)$ & 8.01 \\
Electrical conductivity $\left(\mathrm{dS} \mathrm{m}^{-1}\right)$ & 0.86 \\
Bulk density $\left(\mathrm{g}^{-1} \mathrm{~cm}^{3}\right)$ & 1.67 \\
Sand $(\%)$ & 8.67 \\
Silt $(\%)$ & 52.43 \\
Clay (\%) & 38.90 \\
Textural class & Silty clay loam \\
CaCO $(\%)$ & 14.2 \\
Total organic C $\left(\mathrm{g} \mathrm{kg}^{-1}\right)$ & 8.21 \\
Total N $\left(\mathrm{g} \mathrm{kg}^{-1}\right)$ & 0.52 \\
Field capacity $(\%)$ & 32.81 \\
Permanent wilting point $(\%)$ & 18.41 \\
$\mathrm{AB}-\mathrm{DTPA}$ extractible nutrients & \\
$\mathrm{P}\left(\mathrm{mg} \mathrm{kg}^{-1}\right)$ & 3.78 \\
$\mathrm{~K}\left(\mathrm{mg} \mathrm{kg}^{-1}\right)$ & 104 \\
$\mathrm{Zn}\left(\mathrm{mg} \mathrm{kg}^{-1}\right)$ & 0.84 \\
$\mathrm{Mg}\left(\mathrm{mg} \mathrm{kg}^{-1}\right)$ & 2.21 \\
$\mathrm{Na}\left(\mathrm{mg} \mathrm{kg}^{-1}\right)$ & 2.30 \\
\hline
\end{tabular}

\subsection{Treatments and Field Experiments}

The three-factor two-year field study consisted of four irrigation regimes (I: Irrigation at tillering stage (GS 20-29), II: Irrigation at tillering stage (GS 20-29) + booting stage (GS 41-47), III: Irrigation at tillering stage (GS 20-29) + booting stage (GS 41-47) + flowering stage (GS 61-69), and IV: Irrigation at tillering stage (GS 20-29) + booting stage (GS 41-47) + flowering stage (GS 61-69) + grain filling stage (GS 70-89)), three sowing dates (SD1: 15th November, SD2: 30th November, and SD3: 15th December) and three wheat cultivars (two hybrids cultivars (18A-1 and 18A-2) and a local cultivar (Ghaneemat, IBGE 2016)). The cumulative irrigation under each irrigation regime, including the contribution from rainfall, showed some variations due to the differences in rainfall during the growth years; however, total irrigation amounts under each moisture regime were higher in the year 2019-2020 than in 2018-2019 because of higher rainfall (Table 2). On average, total irrigation provided in 2018-2019 was 95, 172, 249, and $326 \mathrm{~mm}$ for I, II, III, and IV irrigation regimes, respectively; and 110, 179, 259, and $334 \mathrm{~mm}$ for I, II, III, and IV irrigation regimes, respectively, in 2019-2020. Over the two-year period, the average total irrigation was 103, 175, 254, and $330 \mathrm{~mm}$ under I, II, III, and IV irrigation regimes, respectively. The contribution from the rainfall under irrigation regimes also varied with sowing dates in both years. However, despite the variations in contributions from rainfall, the average gradient between the irrigation regimes remained more or less similar, i.e., 77 and $75 \mathrm{~mm}$ in 2018-2019 and 2019-2020, respectively. These water regimes were strategically adopted considering the effects of water deficiency at critical growth stages of wheat as well as excessive irrigation that result in water loss from drainage. Depending on the SDs, compared to normal irrigation, the average water savings under these irrigation regimes over the two growth seasons were $29.4 \%$ and $48.3 \%$ with and without rainfall, respectively (Table S1). 
Table 2. Breakdown of the irrigation provided under different moisture regimes and sowing dates.

\begin{tabular}{|c|c|c|c|c|c|c|c|c|c|c|c|}
\hline \multirow{2}{*}{ Irrigation Regime } & \multirow{2}{*}{ Sowing Dates } & \multirow{2}{*}{$\begin{array}{l}\text { Irrigation } \\
\text { Required } \\
\quad(\mathrm{mm})\end{array}$} & \multicolumn{2}{|c|}{ Rainfall (mm) } & \multicolumn{2}{|c|}{$\begin{array}{l}\text { Irrigation Applied } \\
(\mathrm{mm})\end{array}$} & \multicolumn{2}{|c|}{$\begin{array}{l}\text { Rainfall after Irrigation } \\
\text { (mm) }\end{array}$} & \multicolumn{2}{|c|}{ Total Irrigation (mm) } & \multirow{2}{*}{$\begin{array}{l}\text { Average } \\
\text { Irrigation } \\
\quad(\mathrm{mm})\end{array}$} \\
\hline & & & 2018-2019 & 2019-2020 & 2018-2019 & 2019-2020 & 2018-2019 & 2019-2020 & 2018-2019 & 2019-2020 & \\
\hline \multirow{3}{*}{ I: Irrigation at tillering stage } & 15 November & 77 & 8 & 33 & 69 & 44 & 20 & 35 & 97 & 112 & 105 \\
\hline & 30 November & 77 & 58 & 8 & 19 & 69 & 10 & 23 & 87 & 100 & 94 \\
\hline & 15 December & 77 & 51 & 12 & 26 & 65 & 24 & 42 & 101 & 119 & 110 \\
\hline \multirow{3}{*}{$\begin{array}{l}\text { II: Irrigations at tillering and booting } \\
\text { stages }\end{array}$} & 15 November & 154 & 8 & 41 & 146 & 113 & 20 & 25 & 174 & 179 & 177 \\
\hline & 30 November & 154 & 58 & 29 & 96 & 125 & 10 & 17 & 164 & 171 & 168 \\
\hline & 15 December & 154 & 51 & 51 & 103 & 103 & 24 & 32 & 178 & 186 & 182 \\
\hline \multirow{3}{*}{$\begin{array}{l}\text { III: Irrigations at tillering, booting, and } \\
\text { flowering stages }\end{array}$} & 15 November & 231 & 8 & 45 & 223 & 186 & 20 & 25 & 251 & 256 & 254 \\
\hline & 30 November & 231 & 58 & 38 & 173 & 193 & 10 & 15 & 241 & 246 & 244 \\
\hline & 15 December & 231 & 45 & 76 & 186 & 155 & 24 & 45 & 255 & 276 & 266 \\
\hline \multirow{3}{*}{$\begin{array}{l}\text { IV: Irrigations at tillering, booting, } \\
\text { flowering, and grain filling stages }\end{array}$} & 15 November & 308 & 8 & 33 & 300 & 275 & 20 & 20 & 328 & 328 & 328 \\
\hline & 30 November & 308 & 56 & 76 & 252 & 232 & 10 & 10 & 318 & 318 & 318 \\
\hline & 15 December & 308 & 45 & 99 & 263 & 209 & 24 & 49 & 332 & 357 & 345 \\
\hline
\end{tabular}


The field experiments were conducted following a fully factorial, split-plot, randomized, complete block experimental design with irrigation regime as main plot factor, and each treatment had three replicates. The field was ploughed two times with a cultivator, followed by pulverizing with a rotavator and leveled by using a leveler. The plot size was $12.6 \mathrm{~m}^{2}$ (length $3 \mathrm{~m}$, width $4.2 \mathrm{~m}$ ), accommodating for 14 rows $30 \mathrm{~cm}$ apart per acre. The seeds of hybrid wheat cultivars were provided by Beijing Engineering Research Center China, whereas local wheat cultivar was obtained from the Institute of Biotechnology \& Engineering, The University of Agriculture Peshawar, Pakistan. The crop was planted on three sowing dates, i.e., 15th November, 30th November, and 15th December, using the seed rate of $120 \mathrm{~kg} \mathrm{ha}^{-1}$ following a manual hand hoeing method. Nitrogen, phosphorous, and potassium fertilizers were applied at the rate of 120,80 , and $60 \mathrm{~kg} \mathrm{ha}^{-1}$ using urea, diammonium phosphate (DAP), and muriate of potash (MOP), respectively. All phosphorus and potassium fertilizers were applied at the time of sowing, while nitrogen was applied in split doses at sowing, tillering, and booting growth stages through the broadcast method. Weeds were controlled through herbicide spray Affinity $\left[\mathrm{C}_{3} \mathrm{H}_{14} \mathrm{CLN}_{3}\right.$ (6-chloro-4-N-ethyl-2-Npropan-2-yl-1,3,5-triazine-2,4-diamine)] at 30 days after sowing. Irrigations were provided to plots according to treatments and irrigation regimes using flume instrument so that a precise quaintly of irrigation was applied. Flume was placed in the irrigation channel and leveled through the leveler. The discharge was measured by allowing the canal water to flow through a converged section of flume with a depressed bottom.

\subsection{Plant Measurements and Analysis}

\subsubsection{Phenological Traits}

After the crop emergence, five plants were randomly selected from each treatment plot to record phenological traits' data, including days to tillering, jointing, heading, anthesis, and physiological maturity. Similarly, after collecting the data for physiological maturity, data for grain-filling days were also collected.

\subsubsection{Crop-Water Relations}

The crop-water related parameters, i.e., relative water content (RWC), water saturation deficit (WSD), water uptake capacity (WUC), and water retention capacity (WRC), were determined using the method of Henson et al. [38]. Briefly, three leaves were selected from three randomly sampled plants from each experimental plot and weighed to record fresh weight. These leaf samples were then dipped in glass beakers containing distilled water and kept for $24 \mathrm{~h}$. After $24 \mathrm{~h}$, the samples were taken out, and the turgor weight was recorded. The samples were placed in an oven at $65{ }^{\circ} \mathrm{C}$ for $72 \mathrm{~h}$, and the dry weight was recorded. The crop-water relationship parameters were found using the following formulae:

$$
\begin{gathered}
\operatorname{RWC}(\%)=[(\mathrm{FW}-\mathrm{DW}) /(\mathrm{TW}-\mathrm{DW})] \times 100 \\
\text { WSD }(\%)=[(\mathrm{TW}-\mathrm{FW}) /(\mathrm{TW}-\mathrm{DW})] \times 100 \\
\text { WUC }(\%)=(\mathrm{TW}-\mathrm{FW}) / \mathrm{DW} \\
\text { WRC }(\%)=(\mathrm{TW} / \mathrm{DW}) \times 100
\end{gathered}
$$

where FW is fresh weight $(\mathrm{g})$, DW is dry weight $(\mathrm{g})$, and TW is turgor weight $(\mathrm{g})$.

\subsubsection{Chlorophyll and Carotenoids Contents}

The Soil Plant Analysis Development (SPAD) values of leaves were determined using a digital spade meter (SPAD 502 Plus Chlorophyll Meter, Spectrum Technologies Inc., Aurora, IL, USA). Five plants were selected at random in each treatment plot, and the SPAD values were measured with the digital spade meter from lower, middle, and upper leaves at the anthesis growth stages to reflect the leaf chlorophyll contents.

Chlorophyll $\mathrm{a}$ and $\mathrm{b}$ contents were also determined in green leaves at the anthesis stage. Mature green leaves were sampled from each plot, rinsed with distilled water, and 
dried with blotting paper. For extraction of chlorophyll contents, $0.2 \mathrm{~g}$ leaf samples were ground with $10 \mathrm{~mL}$ of $80 \%$ acetone in a mortar and pestle on ice, and the suspensions were centrifuged at $4000 \mathrm{rpm}$ for $10 \mathrm{~min}$. The extracts were filtered through Whatman\#1 filter papers by giving two $5 \mathrm{~mL} 80 \%$ acetone washings of the mixture to get a final volume of $25 \mathrm{~mL}$ for analysis. The absorbance of the samples was measured at 663 and $645 \mathrm{~nm}$, respectively, on a UV Spectrophotometer (Dynamica Halo DB-20 Series, UK) to find the chlorophyll a and b contents [39].

The same extracts were used to find the carotenoid contents by measuring their absorbance at $480 \mathrm{~nm}$, and carotenoid contents were calculated using the following equation:

$$
\text { Carotenoids }\left(\mathrm{mg} \mathrm{g}^{-1}\right)=\frac{1000 \mathrm{~A}_{480}-2.27 \mathrm{C}_{\mathrm{a}}-81.4 \mathrm{C}_{\mathrm{b}}}{227} \times \mathrm{V} 1000 \times \mathrm{W}
$$

where $\mathrm{A}$ is the absorbance at specific wavelength, $\mathrm{Ca}$ is chlorophyll a contents, $\mathrm{Cb}$ is chlorophyll b contents, $\mathrm{V}$ is final volume of extract, and $\mathrm{W}$ is fresh weight of leaf tissue used.

\subsection{Biological and Grain Yields}

At maturity in the first week of May, six central rows from each treatment plot were harvested to record biomass production and grain yields. After harvesting, the plants were placed in the field for sun drying for three days before grains were separated from straw to weigh the grain and straw biomass to express the biological and grain yields as a ton per hectare $\left(\mathrm{t} \mathrm{ha}^{-1}\right)$

\subsection{Statistical Analysis}

Linear mixed model analysis was applied to find the effects of wheat cultivars (C), sowing dates (SD), and irrigation regimes (I) on phenological traits, water relationships, physiological parameters, and biological and grain yield growth and yield of wheat. Generalized linear mixed model was:

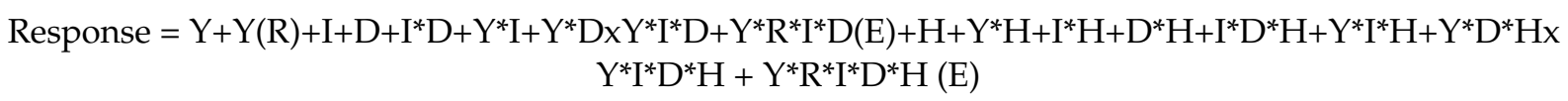

where $\mathrm{Y}$ is the year, $\mathrm{I}$ is irrigation, $\mathrm{D}$ is the sowing date, $\mathrm{H}$ is the hybrid, and (E) refers to the residual error.

Tukey's post hoc test was used for multiple means comparisons by splitting the data into cultivars, irrigation regimes, and sowing dates. Correlation plots were developed to find the relationship of biological and grain yields with phenological and physiological traits. Figures and tables contain mean data of six replicates from two-year experiment unless otherwise specified. Statistical analyses were performed using SPSS for Windows software v. 19.

\section{Results}

\subsection{Effects on Phenological Traits}

Wheat cultivars (C) sowing dates (SD) significantly affected days for tillering, jointing, heading, anthesis, physiological maturity, and grain filling, whereas irrigation regimes (I) showed significant effects on days for heading, anthesis, physiological maturity, and grain filling (Tables S2 and 3). 
Table 3. Effects of irrigation regimes on phenological traits of wheat cultivars sown on different dates.

\begin{tabular}{|c|c|c|c|c|c|c|c|c|c|}
\hline \multirow{3}{*}{$\begin{array}{l}\text { Irrigation } \\
\text { Regimes }\end{array}$} & \multicolumn{9}{|c|}{ Days to Tillering } \\
\hline & \multicolumn{3}{|c|}{15 November } & \multicolumn{3}{|c|}{30 November } & \multicolumn{3}{|c|}{15 December } \\
\hline & IBGE & 18A-1 & 18A-2 & IBGE & 18A-1 & 18A-2 & IBGE & 18A-1 & 18A-2 \\
\hline $\mathrm{I}$ & $45 \pm 2 \mathrm{aA}$ & $43 \pm 1 \mathrm{aA}$ & $47 \pm 2 \mathrm{aA}$ & $42 \pm 1 \mathrm{aA}$ & $44 \pm 1 \mathrm{aA}$ & $46 \pm 1 \mathrm{aA}$ & $35 \pm 1 \mathrm{aA}$ & $41 \pm 5 \mathrm{aA}$ & $39 \pm 1 \mathrm{aA}$ \\
\hline II & $46 \pm 3 \mathrm{aA}$ & $45 \pm 2 \mathrm{aA}$ & $49 \pm 6 \mathrm{aA}$ & $44 \pm 1 \mathrm{aA}$ & $44 \pm 1 \mathrm{aA}$ & $46 \pm 1 \mathrm{aA}$ & $35 \pm 1 \mathrm{aA}$ & $36 \pm 1 \mathrm{aA}$ & $39 \pm 1 \mathrm{bA}$ \\
\hline III & $43 \pm 1 \mathrm{aA}$ & $45 \pm 1 \mathrm{aA}$ & $47 \pm 2 \mathrm{aA}$ & $43 \pm 1 \mathrm{aA}$ & $45 \pm 1 \mathrm{abA}$ & $48 \pm 1 \mathrm{bA}$ & $35 \pm 1 \mathrm{aA}$ & $37 \pm 1 \mathrm{abA}$ & $39 \pm 1 \mathrm{bA}$ \\
\hline \multirow[t]{2}{*}{ IV } & $44 \pm 2 \mathrm{aA}$ & $44 \pm 1 \mathrm{aA}$ & $48 \pm 1 \mathrm{aA}$ & $42 \pm 1 \mathrm{aA}$ & $43 \pm 1 \mathrm{aA}$ & $46 \pm 1 \mathrm{aA}$ & $35 \pm 1 \mathrm{aA}$ & $38 \pm 1 \mathrm{bA}$ & $39 \pm 1 \mathrm{bA}$ \\
\hline & \multicolumn{9}{|c|}{ Days to jointing } \\
\hline $\mathrm{I}$ & $64 \pm 1 \mathrm{aA}$ & $67 \pm 1 \mathrm{aA}$ & $71 \pm 2 \mathrm{bA}$ & $61 \pm 1 \mathrm{aA}$ & $64 \pm 1 \mathrm{aA}$ & $67 \pm 1 \mathrm{bA}$ & $59 \pm 1 \mathrm{aA}$ & $60 \pm 1 \mathrm{abA}$ & $63 \pm 1 \mathrm{bA}$ \\
\hline II & $64 \pm 1 \mathrm{aA}$ & $67 \pm 1 \mathrm{aA}$ & $68 \pm 2 \mathrm{aA}$ & $60 \pm 1 \mathrm{aA}$ & $64 \pm 1 \mathrm{bA}$ & $67 \pm 1 \mathrm{cA}$ & $58 \pm 1 \mathrm{aA}$ & $61 \pm 1 \mathrm{abA}$ & $63 \pm 1 \mathrm{bA}$ \\
\hline III & $63 \pm 1 \mathrm{aA}$ & $65 \pm 1 \mathrm{aA}$ & $70 \pm 1 \mathrm{bA}$ & $61 \pm 1 \mathrm{aA}$ & $64 \pm 1 \mathrm{bA}$ & $67 \pm 1 \mathrm{cA}$ & $59 \pm 1 \mathrm{aA}$ & $61 \pm 1 \mathrm{abA}$ & $65 \pm 2 \mathrm{bA}$ \\
\hline \multirow[t]{2}{*}{ IV } & $63 \pm 1 \mathrm{aA}$ & $66 \pm 1 \mathrm{bA}$ & $69 \pm 1 \mathrm{cA}$ & $60 \pm 1 \mathrm{aA}$ & $62 \pm 1 \mathrm{aA}$ & $66 \pm 1 \mathrm{bA}$ & $59 \pm 1 \mathrm{aA}$ & $60 \pm 1 \mathrm{abA}$ & $63 \pm 1 \mathrm{bA}$ \\
\hline & \multicolumn{9}{|c|}{ Days to heading } \\
\hline I & $100 \pm 1 \mathrm{aA}$ & $\begin{array}{c}107 \pm 2 \\
\mathrm{abA}\end{array}$ & $110 \pm 3 \mathrm{bA}$ & $100 \pm 2 \mathrm{aA}$ & $101 \pm 3 \mathrm{aA}$ & $106 \pm 2 \mathrm{aA}$ & $93 \pm 2 \mathrm{aA}$ & $96 \pm 2 \mathrm{aA}$ & $102 \pm 1 \mathrm{bA}$ \\
\hline II & $114 \pm 4 \mathrm{aB}$ & $123 \pm 2 \mathrm{aB}$ & $123 \pm 4 \mathrm{aB}$ & $101 \pm 3 \mathrm{aA}$ & $\begin{array}{c}108 \pm 3 \\
\mathrm{abA}\end{array}$ & $\begin{array}{c}114 \pm 3 \\
\mathrm{bAB}\end{array}$ & $106 \pm 0 \mathrm{aB}$ & $108 \pm 0 \mathrm{bB}$ & $113 \pm 0 \mathrm{cB}$ \\
\hline III & $134 \pm 4 \mathrm{aC}$ & $129 \pm 3 \mathrm{aB}$ & $\begin{array}{c}132 \pm 5 \\
\mathrm{aBC}\end{array}$ & $113 \pm 1 \mathrm{aB}$ & $119 \pm 2 \mathrm{aB}$ & $\begin{array}{c}120 \pm 4 \\
\mathrm{aBC}\end{array}$ & $106 \pm 2 \mathrm{aB}$ & $107 \pm 2 \mathrm{aB}$ & $111 \pm 2 \mathrm{aA}$ \\
\hline \multirow[t]{2}{*}{ IV } & $131 \pm 2 \mathrm{aC}$ & $\begin{array}{c}137 \pm 2 \\
\mathrm{abC}\end{array}$ & $141 \pm 3 \mathrm{bC}$ & $110 \pm 2 \mathrm{aB}$ & $119 \pm 2 \mathrm{bB}$ & $127 \pm 2 \mathrm{cC}$ & $103 \pm 3 \mathrm{aB}$ & $99 \pm 3 \mathrm{aA}$ & $105 \pm 2 \mathrm{aB}$ \\
\hline & \multicolumn{9}{|c|}{ Days to anthesis } \\
\hline I & $117 \pm 2 \mathrm{aA}$ & $123 \pm 2 \mathrm{aA}$ & $122 \pm 3 \mathrm{aA}$ & $112 \pm 2 \mathrm{aA}$ & $113 \pm 3 \mathrm{aA}$ & $118 \pm 3 \mathrm{aA}$ & $111 \pm 3 \mathrm{aA}$ & $105 \pm 2 \mathrm{aA}$ & $112 \pm 3 \mathrm{aA}$ \\
\hline II & $126 \pm 1 \mathrm{aB}$ & $\begin{array}{c}129 \pm 1 \\
\mathrm{abA}\end{array}$ & $131 \pm 2 \mathrm{bB}$ & $109 \pm 2 \mathrm{aA}$ & $114 \pm 4 \mathrm{aA}$ & $123 \pm 1 \mathrm{bA}$ & $112 \pm 1 \mathrm{aB}$ & $114 \pm 2 \mathrm{aB}$ & $\begin{array}{c}120 \pm 2 \\
\mathrm{bBC}\end{array}$ \\
\hline III & $148 \pm 4 \mathrm{aC}$ & $143 \pm 3 \mathrm{aB}$ & $149 \pm 2 \mathrm{aC}$ & $126 \pm 1 \mathrm{aB}$ & $133 \pm 1 \mathrm{aB}$ & $133 \pm 4 \mathrm{aB}$ & $119 \pm 1 \mathrm{aC}$ & $122 \pm 0 \mathrm{bC}$ & $125 \pm 0 \mathrm{cC}$ \\
\hline \multirow[t]{2}{*}{ IV } & $144 \pm 2 \mathrm{aC}$ & $\begin{array}{c}149 \pm 2 \\
\mathrm{abB}\end{array}$ & $154 \pm 3 \mathrm{cC}$ & $124 \pm 2 \mathrm{aB}$ & $133 \pm 1 \mathrm{bB}$ & $140 \pm 2 \mathrm{cB}$ & $117 \pm 1 \mathrm{aC}$ & $\begin{array}{c}118 \pm 1 \\
\mathrm{aBC}\end{array}$ & $\begin{array}{c}117 \pm 2 \\
\mathrm{aAB}\end{array}$ \\
\hline & \multicolumn{9}{|c|}{ Days to physiological maturity } \\
\hline $\mathrm{I}$ & $143 \pm 2 \mathrm{aA}$ & $152 \pm 1 \mathrm{bA}$ & $157 \pm 1 \mathrm{bA}$ & $144 \pm 2 \mathrm{aA}$ & $151 \pm 1 \mathrm{bA}$ & $154 \pm 1 \mathrm{bA}$ & $141 \pm 1 \mathrm{aA}$ & $142 \pm 1 \mathrm{aA}$ & $147 \pm 1 \mathrm{bA}$ \\
\hline II & $154 \pm 1 \mathrm{aB}$ & $159 \pm 2 \mathrm{aB}$ & $164 \pm 2 b B$ & $143 \pm 1 \mathrm{aA}$ & $149 \pm 1 \mathrm{aA}$ & $144 \pm 6$ aA & $140 \pm 1 \mathrm{aA}$ & $142 \pm 1 \mathrm{aA}$ & $148 \pm 1 \mathrm{bA}$ \\
\hline III & $169 \pm 2 \mathrm{aC}$ & $172 \pm 2 \mathrm{aC}$ & $177 \pm 1 \mathrm{bC}$ & $153 \pm 2 \mathrm{sB}$ & $162 \pm 3 \mathrm{bB}$ & $168 \pm 3 \mathrm{bB}$ & $154 \pm 5 \mathrm{aB}$ & $154 \pm 1 \mathrm{aC}$ & $157 \pm 1 \mathrm{aB}$ \\
\hline IV & $171 \pm 2 \mathrm{aC}$ & $184 \pm 1 \mathrm{bD}$ & $190 \pm 1 \mathrm{cD}$ & $157 \pm 2 \mathrm{aB}$ & $164 \pm 1 \mathrm{bB}$ & $173 \pm 2 \mathrm{cB}$ & $144 \pm 1 \mathrm{aA}$ & $146 \pm 1 \mathrm{aB}$ & $150 \pm 1 \mathrm{bA}$ \\
\hline
\end{tabular}

Values are means of six replicates from two growth cycles followed by standard errors of means $(n=6)$. In a row under each parameter and showing dates, means with different lowercase letters show significant differences between wheat cultivars, and in each column, values with different uppercase letters show significant differences between irrigation regimes at $p<0.05$. I-irrigation at tillering stage; II-irrigations at tillering and booting stages; III—irrigations at tillering, booting, and flowering stages; IV—irrigations at tillering, booting, flowering, and grain filling stages.

Increasing irrigation frequency generally delayed jointing, heading, anthesis, and physiological maturity. For days to tillering, 18A-2 took more days than the local and 18A-1 cultivars at all sowing dates, and the number of days to tillering was reduced with delayed sowing (Table 3). Similarly, days to jointing also decreased with delayed sowing but were significantly higher for the 18A-2 cultivar at all sowing dates. Days to heading increased with irrigation frequency remained higher for the hybrid wheat cultivars and decreased with delay in sowing. Days to anthesis were the highest for 18A-2, which decreased from 154 to 117 days upon delayed sowing from 15th November to 15th December under the irrigation regime IV. Except for the 15th December sowing date, the numbers of days to physiological maturity for the 18A-2 cultivar were significantly higher than the local and 18A-1 cultivars; they increased with irrigation frequency but decreased with delay in sowing (Table 3). At the 15th November sowing date, the 18A-2 cultivar required a greater number of days for grain filling under each moisture regime (Figure 2a). However, the same was true only for irrigation regimes I and III, whereas under the most frequent irrigation regime IV, both wheat hybrids required a smaller number of days for grain filling than the local cultivar (Figure 2b). At the 15th December sowing date under the IV moisture regime, the 18A-2 cultivar took a significantly higher number of days for grain filling compared to the local and 18A-1 cultivars (Figure 2c). 

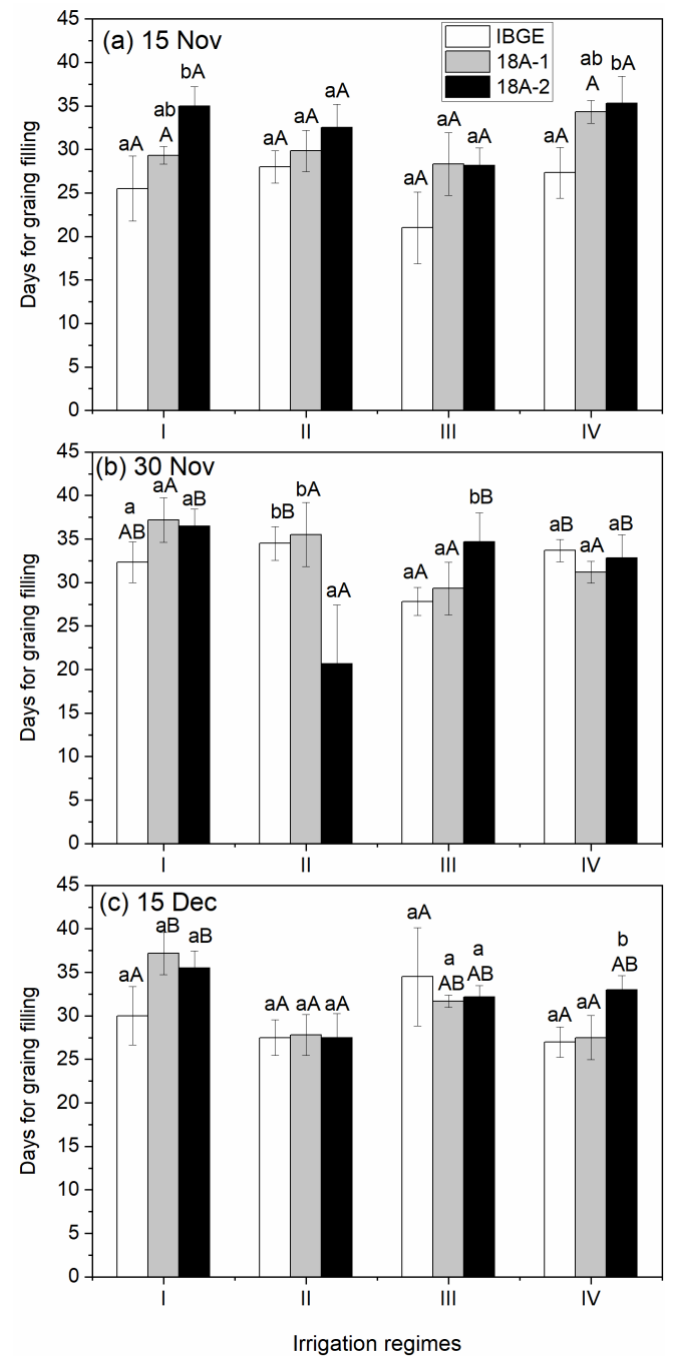

Figure 2. Effects of irrigation regimes on days for grain filling of wheat cultivars sown on different dates. Bars show mean values of six replicates from two growth cycles and contain standard errors of means $(n=6)$. In each panel, bars under each irrigation regime with different lowercase letters show significant differences between wheat cultivars, and bars of each cultivar with different uppercase letters show significant differences between irrigation regimes at $p<0.05$. I-irrigation at tillering stage; II-irrigations at tillering and booting stages; III-irrigations at tillering, booting, and flowering stages; IV-irrigations at tillering, booting, flowering, and grain filling stages. Nov = November, Dec $=$ December.

\subsection{Effects on Physiological Traits}

Wheat cultivars (C), SD, and I showed significant effects on SPAD values (Figure 3; Table S2). Among the wheat cultivars and irrigation regimes, the SPAD values were significantly higher by 53.5 and $49.4 \%$ on earlier showing dates of 15 th November and 30th November (Figure 3a,b) compared to the later sowing date of 15th December (Figure 3c). For the irrigation regimes, the SPAD values were recorded for IV $(52.7 \%)$ followed by III $(52.5 \%)$ compared to the fewer SPAD values under I. The hybrid wheat cultivar 18A-2 showed significantly higher SPAD values followed by the hybrid wheat cultivar 18A-1 compared to fewer SPAD values of local wheat cultivar, particularly on sowing dates of 30th November and 15th December. Interactions between C and SD indicated that SPAD values differed among cultivars with varying sowing dates. Evaluation of chlorophyll contents with respect to the wheat cultivars and sowing dates showed that the local cultivar IBGE sown on 15th November had the highest chlorophyll contents, followed by hybrid 18A-2 sown on 15th December (Figure 3). 

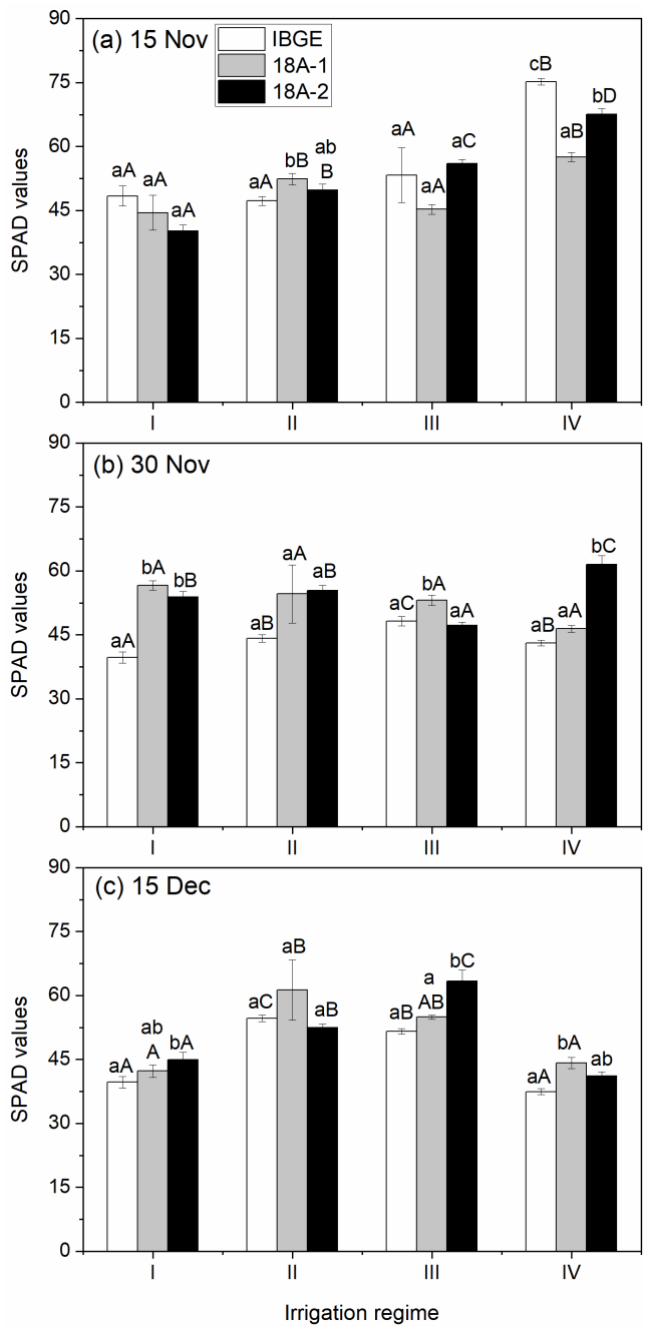

Figure 3. Effects of irrigation regimes on SPAD values of wheat cultivars sown on different dates. Bars show mean values of six replicates from two growth cycles and contain standard errors of means $(n=6)$. In each panel, bars under each irrigation regime with different lowercase letters show significant differences between wheat cultivars, and bars of each cultivar with different uppercase letters show significant differences between irrigation regimes at $p<0.05$. I-irrigation at tillering stage; II-irrigations at tillering and booting stages; III-irrigations at tillering, booting, and flowering stages; IV-irrigations at tillering, booting, flowering, and grain filling stages. Nov=November, Dec $=$ December.

Changes in chlorophyll a, b and carotenoid contents between C, I, and SD are shown in Table 4. Experimental factors SD and I showed significant effects on chlorophyll content (Table S2). Considering wheat cultivars and deficit irrigation regimes, the average chlorophyll contents were higher on sowing dates of 15th November and 30th November than 15th December (Table 4). For the irrigation regimes, the highest chlorophyll contents were found for the IV irrigation regime followed by the III irrigation regime, whereas the lowest chlorophyll a content was observed under I. Earlier sown hybrid wheat cultivars showed significantly higher chlorophyll contents compared to the local cultivar. Moreover, chlorophyll contents decreased with the delay in sowing for local and hybrid wheat cultivars. Effects of experimental factors on chlorophyll $b$ contents were similar to those observed for the chlorophyll contents, and only the sowing dates and irrigation regimes have significant effects on chlorophyll b contents (Tables S2 and 4). On average, the chlorophyll b contents were higher by 10.8 and $9.60 \%$ on 15th November and 30th November sowing dates compared to those on 15th December. Higher chlorophyll b contents were generally observed under the IV irrigation regime and for the hybrid wheat cultivars (Table 4). The 
chlorophyll b contents also decreased with delay in sowing from 15th November to 15 th December for all wheat cultivars.

Table 4. Effects of irrigation regimes on chlorophyll a, chlorophyll b, and carotenoids contents of wheat cultivars sown on different dates.

\begin{tabular}{|c|c|c|c|c|c|c|c|c|c|}
\hline \multirow{3}{*}{$\begin{array}{l}\text { Irrigation } \\
\text { Regimes }\end{array}$} & \multicolumn{9}{|c|}{ Chlorophyll a (mg g ${ }^{-1}$ ) } \\
\hline & \multicolumn{3}{|c|}{15 November } & \multicolumn{3}{|c|}{30 November } & \multicolumn{3}{|c|}{15 December } \\
\hline & IBGE & 18A-1 & $18 \mathrm{~A}-2$ & IBGE & $18 \mathrm{~A}-1$ & $18 \mathrm{~A}-2$ & IBGE & $18 \mathrm{~A}-1$ & $18 \mathrm{~A}-2$ \\
\hline I & $9.13 \pm 0.34 \mathrm{aA}$ & $9.40 \pm 0.38 \mathrm{aA}$ & $9.13 \pm 0.79 \mathrm{a}$ & $\mathrm{A} 9.00 \pm 0.31 \mathrm{aA}$ & $8.47 \pm 0.29 \mathrm{aA}$ & $8.57 \pm 0.28 \mathrm{aA}$ & $8.30 \pm 0.28 \mathrm{bA}$ & $7.83 \pm 0.33 \mathrm{abA}$ & $7.30 \pm 0.33 \mathrm{aA}$ \\
\hline II & $9.27 \pm 0.28 \mathrm{aA}$ & $9.43 \pm 0.37 \mathrm{aA}$ & $9.37 \pm 0.27 \mathrm{aA}$ & $8.87 \pm 0.32 \mathrm{aA}$ & $9.23 \pm 0.27 \mathrm{aA}$ & $9.40 \pm 0.32 \mathrm{aA}$ & $7.87 \pm 0.31 \mathrm{aA}$ & $\begin{array}{l}7.90 \pm 0.29 \mathrm{aA} \\
\end{array}$ & $7.67 \pm 0.39 \mathrm{aA}$ \\
\hline III & $9.53 \pm 0.31 \mathrm{aA}$ & $9.93 \pm 0.27 \mathrm{aA}$ & $9.57 \pm 0.32 \mathrm{aA}$ & $9.40 \pm 0.30 \mathrm{aA}$ & $8.90 \pm 0.28 \mathrm{aA}$ & $8.70 \pm 0.31 \mathrm{aA}$ & $8.17 \pm 0.29 \mathrm{aA}$ & $8.13 \pm 0.29 \mathrm{aA}$ & $7.97 \pm 0.30 \mathrm{aA}$ \\
\hline \multirow[t]{2}{*}{ IV } & $9.53 \pm 0.31 \mathrm{aA}$ & $9.93 \pm 0.27 \mathrm{aA}$ & $10.0 \pm 0.28 \mathrm{aA}$ & $9.63 \pm 0.27 \mathrm{aA}$ & $9.50 \pm 030 \mathrm{aA}$ & $8.83 \pm 0.28 \mathrm{aA}$ & $7.87 \pm 0.29 \mathrm{aA}$ & $7.93 \pm 0.27 \mathrm{aA}$ & $7.90 \pm 0.27 \mathrm{aA}$ \\
\hline & \multicolumn{9}{|c|}{ Chlorophyll b (mg g $\left.{ }^{-1}\right)$} \\
\hline I & $5.03 \pm 0.33 \mathrm{aA}$ & $5.40 \pm 0.32 \mathrm{a}$ & $\mathrm{A} 5.00 \pm 0.34 \mathrm{aA}$ & $4.84 \pm 0.32 \mathrm{aA}$ & $5.27 \pm 0.33 \mathrm{aA}$ & $4.83 \pm 0.32 \mathrm{aA}$ & $3.40 \pm 0.32 \mathrm{aA}$ & $3.73 \pm 0.38 \mathrm{aA}$ & $4.53 \pm 1.13 \mathrm{aA}$ \\
\hline II & $5.38 \pm 0.32 \mathrm{aA}$ & $7.02 \pm 0.33 \mathrm{bB}$ & $6.62 \pm 0.30 \mathrm{bB}$ & $5.38 \pm 0.32 \mathrm{aA}$ & $7.03 \pm 0.49 \mathrm{bB}$ & $6.65 \pm 0.34 \mathrm{bB}$ & $5.12 \pm 0.33 \mathrm{aB}$ & $5.15 \pm 0.31 \mathrm{aB}$ & $4.92 \pm 0.40 \mathrm{aA}$ \\
\hline III & $6.73 \pm 0.35 \mathrm{aB}$ & $7.17 \pm 0.32 \mathrm{aB}$ & $6.77 \pm 0.36 \mathrm{aB}$ & $6.60 \pm 0.34 \mathrm{aB}$ & $6.10 \pm 0.32 \mathrm{aB}$ & $5.90 \pm 0.35 \mathrm{aB}$ & $5.33 \pm 0.32 \mathrm{aB}$ & $5.33 \pm 0.33 \mathrm{aB}$ & $5.17 \pm 0.34 \mathrm{aA}$ \\
\hline \multirow[t]{2}{*}{ IV } & $6.73 \pm 0.35 \mathrm{aB}$ & $7.13 \pm 0.32 \mathrm{a}$ & $6.77 \pm 0.36 \mathrm{aB}$ & $6.63 \pm 0.33 \mathrm{aB}$ & $6.60 \pm 0.34 \mathrm{aB}$ & $6.03 \pm 0.32 \mathrm{aB}$ & $5.07 \pm 0.33 \mathrm{aB}$ & $5.13 \pm 0.32 \mathrm{aB}$ & $5.10 \pm 0.32 \mathrm{aA}$ \\
\hline & \multicolumn{9}{|c|}{ Carotenoids ( $\mathrm{mg} \mathrm{g}^{-1}$ ) } \\
\hline I & $6.17 \pm 1.66 \mathrm{aA}$ & $7.77 \pm 1.85 \mathrm{aA}$ & $6.93 \pm 1.28 \mathrm{aA}$ & $7.27 \pm 2.00 \mathrm{aA}$ & $6.30 \pm 1.40 \mathrm{aA}$ & $7.83 \pm 1.55 \mathrm{aA}$ & $6.90 \pm 1.89 \mathrm{aA}$ & $6.80 \pm 1.54 \mathrm{aA}$ & $7.10 \pm 1.33 \mathrm{aA}$ \\
\hline II & $7.20 \pm 1.98 \mathrm{aA}$ & $8.13 \pm 1.96 \mathrm{aA}$ & $8.40 \pm 1.73 \mathrm{aA}$ & $7.17 \pm 1.97 \mathrm{a}$ & $\mathrm{A} 7.93 \pm 1.90 \mathrm{aA}$ & $8.40 \pm 1.74 \mathrm{aA}$ & $6.63 \pm 1.81 \mathrm{aA}$ & $7.10 \pm 1.64 \mathrm{aA}$ & $7.50 \pm 1.45 \mathrm{aA}$ \\
\hline III & $7.63 \pm 2.12 \mathrm{aA}$ & $8.10 \pm 1.95 \mathrm{aA}$ & $8.30 \pm 1.70 \mathrm{aA}$ & $7.72 \pm 2.14 \mathrm{aA}$ & $7.88 \pm 1.90 \mathrm{aA}$ & $8.03 \pm 1.62 \mathrm{aA}$ & $6.78 \pm 1.84 \mathrm{aA}$ & $7.13 \pm 1.64 \mathrm{aA}$ & $7.42 \pm 1.42 \mathrm{aA}$ \\
\hline IV & $7.63 \pm 2.12 \mathrm{aA}$ & $8.40 \pm 2.04 \mathrm{aA}$ & $8.30 \pm 1.70 \mathrm{aA}$ & $7.85 \pm 2.21 \mathrm{aA}$ & $7.88 \pm 1.87 \mathrm{aA}$ & $8.35 \pm 1.76 \mathrm{aA}$ & $6.78 \pm 1.87 \mathrm{aA}$ & $7.13 \pm 1.66 \mathrm{aA}$ & $7.42 \pm 1.43 \mathrm{aA}$ \\
\hline
\end{tabular}

Values are means of six replicates from two growth cycles followed by standard errors of means $(n=6)$. In each panel, bars under each irrigation regime with different lowercase letters show significant differences between wheat cultivars, and bars of each cultivar with different uppercase letters show significant differences between irrigation regimes at $p<0.05$. I-irrigation at tillering stage; II-irrigations at tillering and booting stages; III-irrigations at tillering, booting, and flowering stages; IV—irrigations at tillering, booting, flowering, and grain filling stages.

Despite noticeable variations in carotenoids contents with respect to C, I, and SD, none of these main experimental factors showed significant effects on carotenoids contents (Tables S2 and 4). However, carotenoids contents were higher in hybrid wheat cultivars and decreased with delay in the sowing dates.

\subsection{Effects on Crop-Water Relations}

Relative water contents (RWC) varied significantly with SD and I experimental factors (Figure 4; Table S2). The hybrid wheat cultivar 18A-1 showed significantly higher RWC, followed by the 18A-2 and local cultivars, respectively (Figure $4 a-c)$. The IV irrigation regime consisting of irrigation at four times over the growth period (tillering, booting, flowering, and grain filling stage) resulted in the highest RWC followed by the irrigation regime III (omitting irrigation at grain filling stage), whereas the lowest RWC was found in plots under irrigation regimes I and II receiving irrigation twice at tillering and booting stages and once only at the tillering stage, respectively. Delay in sowing beyond 15th November significantly reduced RWC. Except for C, the effects of experimental factors and their interactions were significant on WSD (Table S2). Increasing irrigation frequency under I to IV irrigation regimes consistently and significantly decreased WSD for the local wheat cultivar but not always for the hybrid wheat cultivars (Figure $4 \mathrm{~d}-\mathrm{f}$ ). The maximum WSD values were observed under irrigation regime I for local cultivar; however, sowing dates induced significant variations in WSD. On an average basis, sowing on 15th November or 30th November resulted in lower WSD than sowing on 15th December. The results showed that the highest WSD was found for the hybrid wheat cultivar 18A-2 under irrigation regime II sown on 30th December (Figure 4e). 

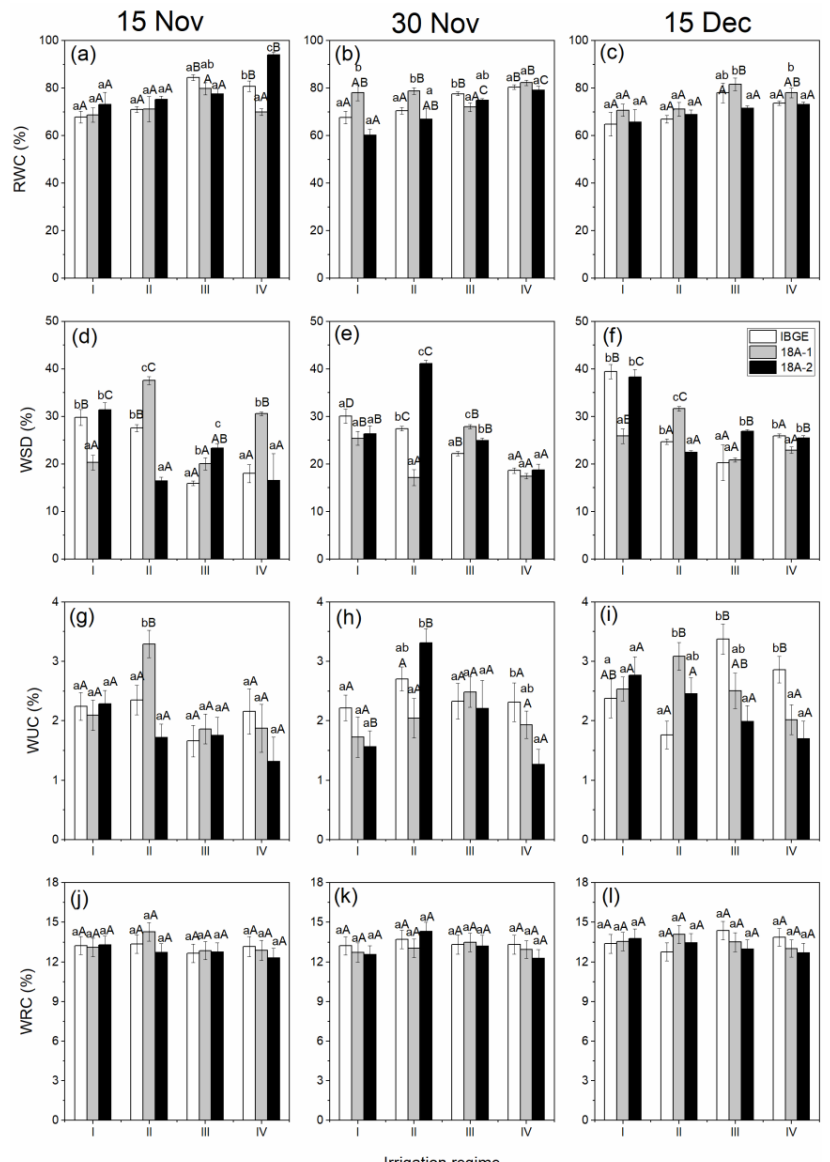

Figure 4. Effects of irrigation regimes on RWC, WSD, WUC, and WRC in wheat cultivars sown on different dates. Bars show mean values of six replicates from two growth cycles and contain standard errors of means $(n=6)$. In each panel, bars under each irrigation regime with different lowercase letters show significant differences between wheat cultivars, and bars of each cultivar with different uppercase letters show significant differences between irrigation regimes at $p<0.05$. I-irrigation at tillering stage; II—irrigations at tillering and booting stages; III—irrigations at tillering, booting, and flowering stages; IV_-irrigations at tillering, booting, flowering, and grain filling stages. Nov $=$ November, Dec $=$ December .

The data on crop-water relations showed that WUC was influenced significantly by experimental factors C, SD, and I (Table S2). The local cultivar IBGE showed significantly higher WUC than the hybrid cultivars, and among these hybrid cultivars, 18A-1 had fewer WUC values than 18A-2 (Figure 4g-i). The irrigation regime IV resulted in significantly lower WUC values compared to other irrigation regimes. Delay in sowing time drastically increased WUC. Sowing the wheat cultivars on 15th November had the lowest WUC values in contrast to the highest WUC values on 15th December. In contrast to RWC, WSD, and WUC, none of the experimental factors induced significant effects on WRC (Table S2). The data further showed the non-consistent variations in WRC values (Figure 4j-1).

\subsection{Effects on Biological and Grain Yields}

The effects of C, SD, and I are shown in Figure 5 and Table S2. The biological yield of hybrid wheat cultivars was always significantly higher than the local cultivar at all sowing dates, and the 18A-2 cultivar showed the highest biological yield (Figure 5a-c). Biological yield for each cultivar decreased with a delay in sowing time from 15th November to 15th December. The hybrid wheat cultivars consistently produced higher biomass compared to the local cultivar under all irrigation regimes at each sowing date; however, the differences between the two hybrid wheat cultivars were not always significant. Trends in the effects 
of main factors $\mathrm{C}, \mathrm{SD}$, and I on grain yield were similar to those of biological yield and were always significant (Table S2). Grain yield of hybrid wheat cultivars was higher than the local cultivar, whereas 18A-2 cultivar produced the highest grain yield at all sowing dates (Figure $5 \mathrm{~d}-\mathrm{f}$ ). When sown earlier on 15th November, grain yield of 18A-2 cultivar was the highest under the irrigation regimes III and IV, and similar effects were found for the sowing date of 30th November. On 15th December sowing date, differences of grain yield between irrigation regimes for each cultivar were non-consistent, but the grain yield remained the highest for the 18A-2 cultivar under III and IV irrigation regimes (Figure 5f).
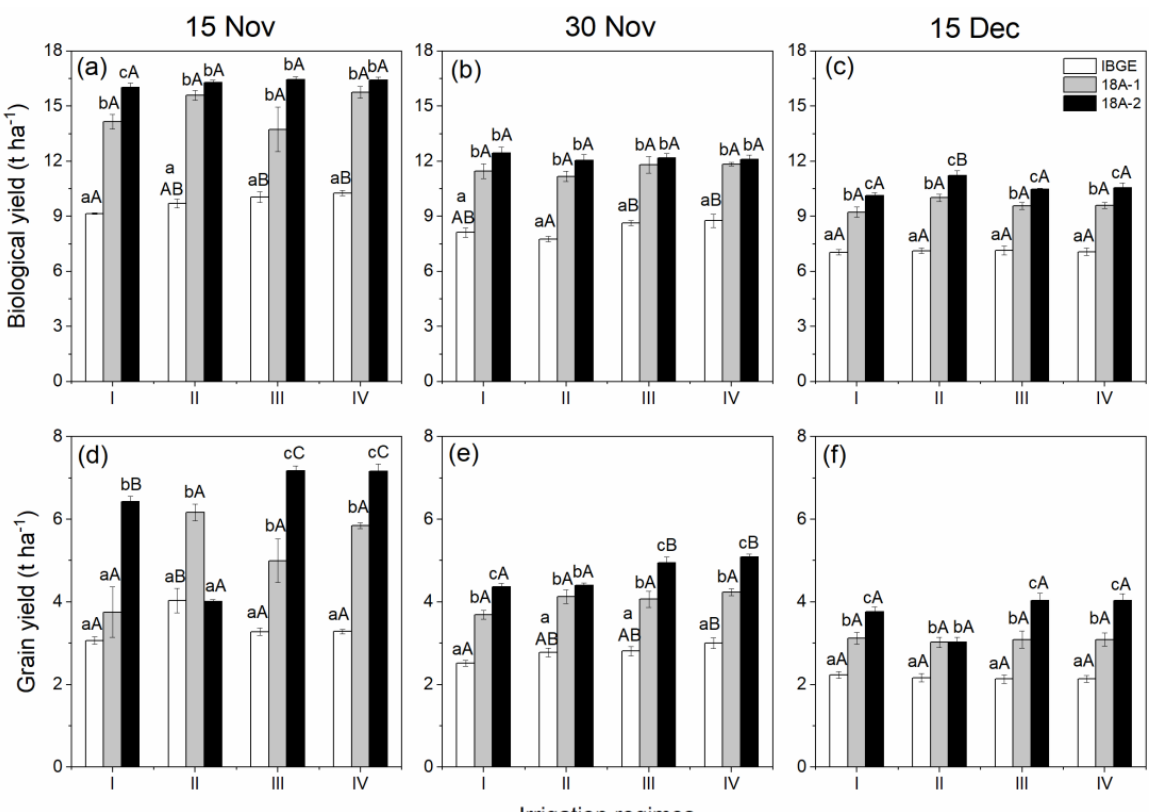

Figure 5. Effects of irrigation regimes on biological and grain yields of wheat cultivars sown on different dates. Bars show mean values of six replicates from two growth cycles and contain standard errors of means $(n=6)$. In each panel, bars under each irrigation regime with different lowercase letters show significant differences between wheat cultivars, and bars of each cultivar with different uppercase letters show significant differences between irrigation regimes at $p<0.05$. I-irrigation at tillering stage; II—irrigations at tillering and booting stages; III-irrigations at tillering, booting, and flowering stages; IV-irrigations at tillering, booting, flowering, and grain filling stages. Nov $=$ November, Dec $=$ December .

\subsection{Correlations of Biological and Grain Yields with Crop Traits}

The relationships of biological and grain yields with SPAD values, days to maturity, and days to grain filling are showed in Figure 6. The biological and grain yields were significantly positively correlated with SPAD values (Figure 6a,b). The relationships of biological and grain yields with days to maturity were significant positive and were much stronger (Figure $6 \mathrm{c}, \mathrm{d}$ ). However, the correlations of biological and grain yields with days for grain filling were negative and non-significant (Figure 6e,f). 

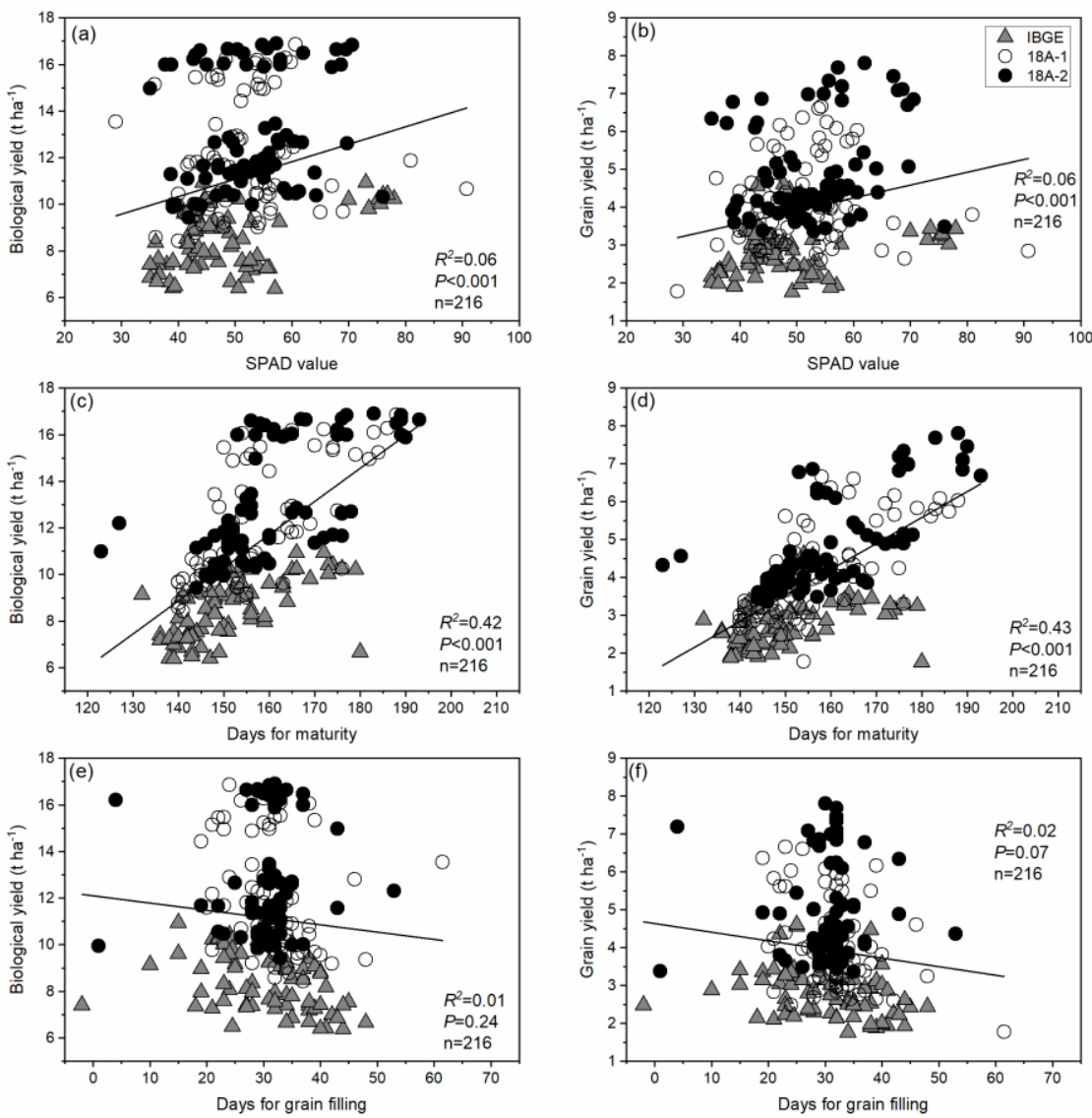

Figure 6. Correlations of biological and grain yields with SPAD values, days for maturity, and days for grain filling.

\section{Discussion}

This study observed that the irrigation regimes and sowing dates significantly influenced the chlorophyll traits, i.e., SPAD values, chlorophyll a and b contents, and carotenoids of wheat hybrids. Irrigation, cultivar and crop management practices can affect the chlorophyll contents, which alter the other physiological attributes of plants. Chlorophyll molecules are the main component and are essential for harvesting light energy in photosynthesis and all physiological responses [40]. Thomas et al. [41] noticed that chlorophyll contents play a dominant role in achieving a higher photosynthetic rate and showed a significant and positive correlation between photosynthetic rate and SPAD values. As the sowing intervals are delayed, greater variations occur among the cultivars for chlorophyll contents [42]. The accumulation of both chlorophyll $a$ and $b$ contents decreased under stressed conditions [43]. Chlorophyll a and $\mathrm{b}$ molecules have distinct characteristics based on their varying chemical structures, which enable them to absorb specific infrared light by acting as photoreceptors and perform photosynthetic functions to convert sunlight into chemical energy [44,45]. Irakli et al. [46] reported that chlorophyll contents reduced under abiotic stress such as water, light, and salinity. The drought-tolerant wheat cultivars showed much higher chlorophyll a and $\mathrm{b}$ contents and better morpho-physiological traits under water-deficit conditions, which served as important characteristics for hybrid cultivar development [47]. The SPAD values in our study were significantly influenced by cultivars, sowing dates, and irrigation regimes, and they were significantly positively correlated with biological and grain yields. The SPAD values generally reflect the chlorophyll contents in leaves and are a reliable indicator of plant growth, development, and physiological health under diverse growth conditions [48,49]. Ayer et al. [50] also demonstrated significant positive relationships of SPAD values with biological and grain yields and harvest index for various wheat genotypes. 
In this study, late sowing hastened booting, heading, anthesis, and maturity, and it caused a significant reduction in yield and yield components of wheat but much less for the hybrid cultivars. Moreover, the local cultivar required significantly less time to complete phenological growth stages for different sowing dates than the hybrid cultivars, which directly influenced their performance and adaptability. The presence of environmental stresses such as drought, moisture, and temperature can have pronounced effects on the plant developmental stages, including germination, tillering, booting, heading, anthesis, and maturity [51]. On the late sowing dates, a rise in temperature may impair the grain filling stage [51]. We found that the hybrid wheat cultivars exhibited a prolonged grain filling period than the local cultivars suggesting means more time for photosynthate accumulation in the grains and, ultimately, higher yield grain yields [52,53]. These observations are supported by the positive relationships of biological and grain yields with SPAD values and days for maturity. Our findings are also consistent with Hossain and Da Silva [54], who reported that the late-sown wheat faced high-temperature stress at later growth stages, completed heading, grain filling, and grain maturity earlier than early sown wheat crop, and resulted in fewer grain yields. For the late-sowing dates, the inferior growth of the local cultivar compared to the hybrid cultivars might indicate decreased photosynthesis activity, carbohydrate translocation, and assimilation [55]. Similar to our study, Mumtaz et al. [56] reported the wheat crop sown late on 21 December took below-optimal days for booting, heading, anthesis, and maturity. Late sowing can expose the crop to low temperatures at the time of emergence, delay emergence, and reduce growth rate, which leads to dwarf plants, fast heading, and less time for grain filling and maturity, and ultimately result in low biomass production and grain yield [57,58]. Conversely, our results showed that the optimum sowing time resulted in more days to tillering, jointing, heading, anthesis, and maturity, which correlated significantly positively with biological and grain yields. However, cooler temperatures have been reported to delay flowering and maturity $[59,60]$. Spink et al. [57] demonstrated that delayed sowing shortened the duration of each development phase due to a rise in temperature. The reason for a decrease in the anthesis days could be a high temperature in for the late-sown dates, which reduced the length of growth period. However, the temperature generally immediately increases after mid-March and may reach beyond $30^{\circ} \mathrm{C}$ by the end of March along the increase in day length forcing the crop to complete the cycle rather quickly [61,62]. Therefore, the late-sown crop generally has little time for optimum growth and development. In addition, the irrigation stress can also shorten the growing period of crops and accelerate their phenological traits such as heading, booting, anthesis, and maturity [63]. The limited ability of plants for nutrient uptake and photosynthetic efficiency under heat and drought stress can also reduce organ size (leaf, tiller, and spikes) and growth periods during various development stages of tillering, jointing, booting, heading, anthesis, and grain filling [64]. The plant sensitivity to drought and high temperature may result in disturbed metabolic processes coupled with a shorter plant life cycle and, consequently, reduce plant biomass accumulation and grain yield [65-67]. However, our study showed that the hybrid wheat cultivars were better adapted to these stresses and performed better than the local cultivar in Pakistan.

The crop-water traits of wheat hybrids, i.e., RWC, WSD, WUC, and WRC, were significantly affected by deficit water irrigation regimes and sowing dates in our study. Osmotic adjustment is a process of accumulating solutes in plants for lowering soil water potential to alleviate the negative effects of water stress and, thus, increase the permeability of cells [68,69]. Relative water content is considered to be an essential indicator of water stress in leaves and shows a direct relationship to soil water contents. Ranney et al. [70] reported that the osmotic adjustment mechanism reduces the osmotic potential of cells and maintains the turgor of tissues under water stress. Our study showed that hybrid wheat cultivars adapted efficiently to reduced water availability by possibly improving crop-water relations under deficient irrigation primarily due to maintenance of cell turgor and osmotic potential [71-73]. When the rate of transpiration exceeds the absorption process, it results in decreased water content in leaves, and ultimately, cell volume, stomatal 
conductance, and relative water content are decreased due to low cell turgor [74]. Blum [75] showed that enhancing transpirational efficiency under deficient and optimum moisture conditions can improve WUE and crop productivity under dryland conditions. Leaf tissue turgor pressure is controlled by the process of leaf water content and helps to maintain leaf activity for the maximum photosynthetic rates [76,77]. Our study showed that higher WUC, WSD, and WRC could be attained by irrigation given at once, whereas more availability of water to the crop reduced the WUC, WSD, and WRC in wheat crop [64]. Similar to our findings, Guendouz et al. [78] showed that irrigation conditions and WUE strongly influenced the grain yield of durum wheat cultivars. Improved crop-water relationships offer substantial opportunities to improve WUE by using deficit irrigation, soil water, and nutrient management approaches under varying agro-climatic conditions [79,80].

Our study showed that wheat cultivars, irrigation regimes, and sowing dates significantly affected wheat biomass production and grain yield. Wheat crop sown at appropriate time generally results in higher biological and grain yields, which show linear relationships with photosynthetic activity, plant productivity, and grain yields [57,81]. Hussain et al. [82] noticed hindrance in germination process and crop growth rate with delay in sowing, which resulted in a reduced number of tillers $\mathrm{m}^{-2}$, biomass production, and yield. In the present study, we also found a substantial decrease of $44 \%$ in grain yield with delay in sowing from 15th November to 30th November and further delay to 15th December reduced yield by $27 \%$ across both the local and hybrid wheat cultivars. The decrease in grain and biological yield with delay in sowing might be due to the rise in temperature at reproductive phase that decreased the photosynthate assimilation efficiency and the number of productive days [83]. Such reduction in grain and biological yield due to the delayed sowing has also been reported previously [84-86]. Irrigation regimes coupled with sowing dates are important factors influencing crop yield and yield contributing traits, and water stress can adversely affect the number of grains spike ${ }^{-1}$, tillers $\mathrm{m}^{-2}$, and biomass production $[87,88]$. We found that the decrease in crop yield under deficit irrigation may be due to the production of fewer photosynthates and translocation of the assimilate to the competitive sink. The optimal irrigation required at critical stages increased crop biological and grain yields due to maximum photosynthates production in leaves. This could lead to better development of grains under optimal nutrients supply because water deficiency causes reverse osmosis resulting in lower grain and biological yields [89,90]. Prey et al. [91] compared the nitrogen use efficiency and $C$ allocation potential of high yield hybrid wheat cultivars with local wheat breeds to show that hybrid cultivars produced higher grain yields attributed to higher harvest index, post-anthesis photosynthate assimilation, and grains per spike. Zhou et al. [92] found higher grain yields of hybrid rice due to improved WUE and crop-water relationships under water-deficit conditions. In addition to deficit irrigation, micro-irrigation, deficit drip irrigation, and planting patterns can also enhance WUE under drought-prone conditions [93-95]. However, productivity and WUE of hybrid crop cultivars can also strongly depend on agronomic practices and climatic conditions, e.g., Buczek [96] reported that grain yield and quality of hybrid wheat varied significantly with tillage practices, whereas Rezaei et al. [97] found that phenology of wheat cultivars varied climatic changes. As reported in our study, hybrid wheat can result in major yield increases and ensure food security by counterbalancing the extreme environmental conditions, including heat and drought stress [98,99]. However, despite the promising potential of the hybrid wheat cultivars under varying sowing dates and deficient moisture, large-scale adaptability and yield stability of these cultivars require more research by applying various tools such as statistical models, multi-environmental trials, and farmer surveys in Pakistan [100-102].

\section{Conclusions}

Cultivation and optimization of hybrid wheat cultivars to obtain higher biomass production and grain yield under less irrigation water are relatively new in the wheatgrowing belt in Pakistan. Our three-factor (wheat cultivars, sowing dates, and irrigation 
regimes) two-year field study showed that deficit irrigation improved the crop-water relations and crop yields. The early sowing improved RWC, chlorophyll content, and WUE under deficit irrigation as compared to the late sowing under full irrigation scenarios. The Chinese hybrid wheat cultivar 18A-2 performed better with improved crop-water relationships and higher yield under deficit irrigations. Moreover, the hybrid 18A-2 cultivar had higher chlorophyll contents when sowing early compared with the local cultivar. The hybrid cultivars took more days to maturity and grain filling. Our study further showed that both hybrid wheat cultivars produced higher biological and grain yields than the local cultivar at all sowing dates but biological and grain yields decreased with delay in sowing; however, the decline in yield with delayed sowing was more prominent in the local cultivar. Both the biological and grain yields were correlated significantly positively with SPAD values and days to maturity. Furthermore, the provision of irrigation at the three (tillering, booting, and flowering) and four (tillering, booting, flowering, and grain filling) critical growth stages resulted in the optimum biomass production and grain yield. The hybrid wheat cultivars were better adapted to deficit irrigation and delayed sowing by producing higher biomass and crop yields under semi-arid climatic conditions in Pakistan. By adopting deficient irrigation strategies, wheat crop was protected against water deficiency as well as over-irrigation and resulted in water saving both with and without rainfall. This study reports pioneer work on hybrid wheat cultivation under semi-arid climatic conditions of Pakistan and, therefore, more work is required to test the potential of hybrid wheat on a wider scale for its adaptability, yield-stability, profitability, and commercialization.

Supplementary Materials: The following are available online at https:/ /www.mdpi.com/article/ 10.3390/agronomy11101976/s1, Table S1: Historical weather conditions at the study site; Table S2: F statistics of linear mixed models for the effects of wheat cultivars, sowing dates and irrigation regimes on growth and yield of wheat.

Author Contributions: Conceptualization, M.M.A. and M.A.; methodology, M.M.A., M.A. and M.R.; formal analysis, M.A., M.R. and K.A.; investigation, M.M.A. and M.A.; resources, M.A., S.Q.Z. and C.P.Z.; data curation, M.M.A., M.A. and M.R.; writing—original draft preparation, M.M.A., M.A. and M.R.; writing-review and editing, M.A., M.R., K.A., S.Q.Z. and C.P.Z.; visualization, M.A., M.R. and K.A.; supervision, M.A.; project administration, M.A.; funding acquisition, M.A., S.Q.Z. and C.P.Z. All authors have read and agreed to the published version of the manuscript.

Funding: This work was partly supported by the Beijing Science and Technology Program (Z191100004019014), Science and Technology Innovation Project of BAAFS (KJCX20210439), Beijing Scholars Program,, Modern Agro-Industry Technology Research System of China (CARS-3), and the Creation of Water-efficient Hybrid Wheat for Pakistan and China' Project No.PSF/NSFC/Agr-KPAUP(14) funded by Pakistan Science Foundation, Islamabad, Pakistan.

Institutional Review Board Statement: Not applicable.

Informed Consent Statement: Not applicable.

Data Availability Statement: Data are available on request.

Conflicts of Interest: The authors declare no conflict of interest.

\section{References}

1. IPCC. 2021: Summary for Policymakers. In Climate Change 2021: The Physical Science Basis. Contribution of Working Group I to the Sixth Assessment Report of the Intergovernmental Panel on Climate Change; Masson-Delmotte, V., Zhai, P., Pirani, A., Connors, S.L., Péan, C., Berger, S., Caud, N., Chen, Y., Goldfarb, L., Gomis, M.I., et al., Eds.; Cambridge University Press: Cambridge, UK, 2021.

2. Kang, S.; Zhang, L.; Liang, Y.; Hu, X.; Cai, H.; Gu, B. Effects of limited irrigation on yield and water use efficiency of winter wheat in the Loess Plateau of China. Agric. Water Manag. 2002, 55, 203-216. [CrossRef]

3. Daryanto, S.; Wang, L.; Jacinthe, P.A. Global synthesis of drought effects on cereal, legume, tuber and root crops production: A review. Agric. Water Manag. 2017, 179, 18-33. [CrossRef]

4. Dinar, A.; Tieu, A.; Huynh, H. Water scarcity impacts on global food production. Glob. Food Sec. 2019, 23, 212-226. [CrossRef]

5. Cakir, R. Effect of water stress at different development stages on vegetative and reproductive growth of corn. Field Crop. Res. 2004, 89, 1-16. [CrossRef] 
6. Du, T.; Kang, S.; Sun, J.; Zhang, X.; Zhang, J. An improved water use efficiency of cereals under temporal and spatial deficit irrigation in north China. Agric. Water Manag. 2010, 97, 66-74. [CrossRef]

7. Li, Q.; Bian, C.; Liu, X.; Ma, C.; Liu, Q. Winter wheat grain yield and water use efficiency in wide-precision planting pattern under deficit irrigation in North China Plain. Agric. Water Manag. 2015, 53, 71-77. [CrossRef]

8. Kalamartzis, I.; Dordas, C.; Georgiou, P.; Menexes, G. The use of appropriate cultivar of basil (Ocimum basilicum) can increase water use efficiency under water stress. Agronomy 2020, 10, 70. [CrossRef]

9. Zhang, H.P.; Oweis, T. Water yield relation and optimal irrigation scheduling of wheat in Mediterranean regions. Agric. Water Manag. 1998, 3, 195-211. [CrossRef]

10. Tari, A.F. The effects of different deficit irrigation strategies on yield, quality, and water-use efficiencies of wheat under semi-arid conditions. Agric. Water Manag. 2016, 167, 1-10. [CrossRef]

11. James, R.M.; Andrew, W.; Paxton, P. Deficit irrigation in a production setting: Canopy temperature as an adjunct to ET estimates. Irrig. Sci. 2012, 30, 127-137.

12. Zhong, Y.; Shangguan, Z. Water consumption characteristics and water use efficiency of winter wheat under long-term nitrogen fertilization regimes in Northwest China. PLoS ONE 2014, 9, e98850. [CrossRef]

13. Yufeng, Z.; Saddique, Q.; Ajaz, A.; Jiatun, X.; Khan, M.I.; Mu, Q.; Azmat, M.; Cai, H.; Siddique, K.H.M. Deficit irrigation improves maize yield and water use efficiency in a semi-arid environment. Agric. Water Manag. 2021, 243, 106483.

14. Soundharajan, B.; Sudheer, K.P. Deficit irrigation management for rice using crop growth simulation model in an optimization framework. Paddy Water Environ. 2009, 7, 135-149. [CrossRef]

15. Katerji, N.; Campi, P.; Mastrorilli, M. Productivity, evapotranspiration, and water use efficiency of corn and tomato crops simulated by AquaCrop under contrasting water stress conditions in the Mediterranean region. Agric. Water Manag. 2013, 130, 14-26. [CrossRef]

16. Neal, J.S.; Murphy, S.R.; Harden, S.; Fulkerson, W.J. Differences in soil water content between perennial and annual forages and crops grown under deficit irrigation and used by the dairy industry. Field Crop. Res. 2012, 137, 148-162. [CrossRef]

17. Istanbulluoglu, A.; Arslan, B.; Gocmen, E.; Gezer, E.; Pasa, C. Effects of deficit irrigation regimes on the yield and growth of oilseed rape (Brassica napus L.). Biosyst. Eng. 2010, 105, 388-394. [CrossRef]

18. Jha, P.K.; Kumar, S.N.; Ines, A.V. Responses of soybean to water stress and supplemental irrigation in upper Indo-Gangetic plain: Field experiment and modeling approach. Field Crop. Res. 2018, 219, 76-86. [CrossRef]

19. Adu, M.O.; Yawson, D.O.; Armah, F.A.; Asare, P.A.; Frimpong, K.A. Meta-analysis of crop yields of full, deficit and partial root-zone drying irrigation. Agric. Water. Manag. 2018, 197, 79-90. [CrossRef]

20. Ahmadi, S.H.; Andersen, M.N.; Plauborg, F.; Poulsen, R.T.; Jensen, C.R.; Sepaskhah, A.R.; Hansen, S. Effects of irrigation strategies and soils on field grown potatoes: Gas exchange and xylem [ABA]. Agric. Water. Manag. 2010, 97, 1486-1494. [CrossRef]

21. Li, Q.Q.; Lang, K.; Liu, Q.R.; Bian, C.Y.; Liu, X.H.; Chen, G.Q. Dry matter, grain yield, and evapo-transpiraiton of winter wheat under deficit irrigation in North China Plain. J. Food Agric. Environ. 2013, 11, 2593-2596.

22. Li, H.; Qi, Z.; Gui, D.; Zeng, F. Water use efficiency and yield responses of cotton to field capacity-based deficit irrigation in an extremely arid area of China. Int. J. Agric. Biol. Eng. 2019, 12, 91-101. [CrossRef]

23. Zhang, P.; Wei, T.; Li, Y.; Zhang, Y.; Cai, T.; Ren, X.; Han, O.; Jia, Z. Effects of deficit irrigation combined with rainwater harvesting planting system on the water use efficiency and maize (Zea mays L.) yield in a semiarid area. Irrig. Sci. 2019, 37, 611-625. [CrossRef]

24. Gadédjisso-Tossou, A.; Avellán, T.; Schütze, N. Potential of Deficit and Supplemental Irrigation under Climate Variability in Northern Togo, West Africa. Water 2018, 10, 1803. [CrossRef]

25. Abd El-Monem, E.S.M.; Young, J.C.; Rabalski, I.; Hucl, P.; Fregeau-Reid, J. Identification and quantification of seed carotenoids in selected wheat species. J. Agric. Food Chem. 2007, 55, 787-794. [CrossRef] [PubMed]

26. Mostafa, H.A.M.; Hassanein, R.A.; Khalil, S.I.; El-Khawas, S.A.; El-Bassiouny, H.M.S.; Abd El-Monem, A.A. Effect of arginine or putrescine on growth, yield and yield components of late sowing wheat. J. Appl. Sci. Res. 2010, 6, 177-183.

27. MNFSR. Agriculture Statistics of Pakistan; Ministry of National Food Security and Research: Islamabad, Pakistan, 2015.

28. Mukhtarullah, J.A.; Akmal, M. Yield comparison of some improved wheat varieties under different sowings dates as rainfed crop. Sarhad J. Agric. 2016, 32, 89-95. [CrossRef]

29. Upadhyay, R.G.; Ranjan, R.; Negi, P.S. Influence of sowing dates and varieties on productivity of wheat under mid Himalayan region of Uttarkhand. Inter. J. Trop. Agr. 2015, 33, 1905-1909.

30. Naz, G.; Akmal, M. Yield and yield contributing traits of wheat varieties affected by N-rate. Sarhad J. Agric. 2016, 3, 212-217. [CrossRef]

31. Bai, J.F.; Wang, Y.K.; Wang, P.; Duan, W.J.; Yuan, S.H.; Sun, H.; Yuan, G.L.; Ma, J.X.; Wang, N.; Zhang, F.T.; et al. Uncovering male fertility transition responsive miRNA in a wheat photo-thermosensitive genic male sterile line by deep sequencing and degradome analysis. Front. Plant Sci. 2017, 8, 1370. [CrossRef]

32. Gupta, P.K.; Balyan, H.S.; Gahlaut, V.; Saripalli, G.; Pal, B.; Basnet, B.R.; Joshi, A.K. Hybrid wheat: Past, present and future. Theor. Appl. Genet. 2019, 132, 2463-2483. [CrossRef]

33. FAO. Production Quantities of Wheat by Country. 2019. Available online: http://www.fao.org/faostat/en/\#data/QC/visualize (accessed on 25 January 2021). 
34. IndexMundi. Wheat Yield by Country. 2020. Available online: https://www.indexmundi.com/agriculture/?commodity=wheat\& graph=yield (accessed on 25 January 2021).

35. Khan, I.; Lei, H.; Khan, A.; Muhammad, I.; Javeed, T.; Khan, A.; Huo, X. Yield gap analysis of major food crops in Pakistan: Prospects for food security. Environ. Sci. Pollut. Res. 2021, 28, 7994-8011. [CrossRef] [PubMed]

36. Fiaz, S.; Khan, S.A.; Noor, M.A.; Younas, A.; Ali, H.; Ali, K.; Gaballah, M.M.; Anis, G.B. Genome engineering for food security. In Genome Engineering for Crop Improvement; Upadhyay, S.K., Ed.; John Wiley \& Sons: Hoboken, NJ, USA, 2021; pp. 380-390.

37. Henson, I.E.; Mahakashmaly, V.; Bidinger, E.R.; Alagarswamy, G. Genotypic variation in pearl millet (Pennisetum americanum Leeke) in the ability to accumulate abscisic acid in response to water stress. Expo. Bot. 1981, 32, 899-910. [CrossRef]

38. Arnon, D.I. Copper enzymes in chloroplasts. Phenol oxidase in Beta vulgaris. Plant Physiol. 1949, $24,1-15$.

39. Kang, Z.; Li, G.; Huang, J.; Niu, X.; Zou, H.; Zang, G. Photosynthetic and physiological analysis of the rice high-chlorophyll mutant (gc). Plant Physiol. Biochem. 2012, 60, 81-87. [CrossRef]

40. Thomas, J.A.; Jaffrey, A.C.; Atsuko, K.; David, M.K. Regulating the proton budget of higher plant photosynthesis. Proc. Natl. Acad. Sci. USA 2005, 102, 9709-9713.

41. Pande, P.; Verma, R.S. Sowing date and varietal effects on chlorophyll content and photosynthetic rate of wheat. Pantnagar. J. Res. 2011, 9, 8-11.

42. Adom, K.K.; Sorrells, M.E.; Liu, R.H. Phytochemical profiles and antioxidant activity of wheat varieties. J. Agric. Food Chem. 2004, 51, 7825-7834. [CrossRef]

43. Hentschel, V.; Kranl, K.; Hollmann, J.; Lindhauer, M.G.; Böhm, V.M.; Bitsch, R. Spectrophotometric determination of yellow pigment content and evaluation of carotenoids by high-performance liquid chromatography in durum wheat. J. Agric. Food Chem. 2002, 50, 6663-6668. [CrossRef]

44. Panfili, G.; Fratianni, A.; Irano, M. Improved normal-phase high-performance liquid chromatography procedure for the determination of carotenoids in cereals. J. Agric. Food Chem. 2004, 52, 6373-6377. [CrossRef] [PubMed]

45. Irakli, M.N.; Samanidou, V.F.; Papadoyannis, I.N. Development and validation of an HPLC method for the simultaneous determination of tocopherols, tocotrienols and carotenoids in cereals after solid-phase extraction. J. Sep. Sci. 2011, 34, 1375-1382. [CrossRef] [PubMed]

46. Ahmed, H.G.M.; Zeng, Y.; Yang, X.; Anwaar, H.A.; Mansha, M.Z.; Hanif, C.M.S.; Ikran, K.; Ullah, A.; Alghanem, S.M.S. Conferring drought-tolerant wheat genotypes through morpho-physiological and chlorophyll indices at seedling stage. Saudi J. Biol. Sci. 2020, 27, 2116-2123. [CrossRef]

47. Jiang, C.; Johkan, M.; Hohjo, M.; Tsukagosh, S.; Maruo, T. A correlation analysis on chlorophyll content and SPAD value in tomato leaves. HortResearch 2017, 71,37-42.

48. Yue, X.; Hu, Y.; Zhang, H.; Schmidhalter, U. Evaluation of both SPAD reading and SPAD index on estimating the plant nitrogen status of winter wheat. Int. J. Plant Prod. 2020, 14, 67-75. [CrossRef]

49. Ayer, D.; Sharma, A.; Ojha, B.; Paudel, A.; Dhakal, K. Correlation and path coefficient analysis in advanced wheat genotypes. SAARC J. Agric. 2017, 15, 1-12. [CrossRef]

50. Ihsan, M.Z.; El-Nakhlawy, F.S.; Ismail, S.M.; Fahad, S.; Daur, I. Wheat phenological development and growth studies as affected by drought and late season high temperature stress under arid environment. Front. Plant Sci. 2016, 7, 795. [CrossRef] [PubMed]

51. Araus, J.L.; Slafer, G.A.; Royo, C.; Serret, M.D. Breeding for yield Potential and stress adaptation in cereals. Crit. Rev. Plant Sci. 2008, 27, 377-412. [CrossRef]

52. Tuberosa, R. Phenotyping for drought tolerance of crops in the genomics era. Front. Physiol. 2012, 3, 347. [CrossRef] [PubMed]

53. Hossain, A.; DaSilva, J.A.T. Phenology, growth and yield of three wheat (Triticum aestivum L.) varieties as affected by high temperature stress. Not. Sci. Biol. 2012, 4, 97-109. [CrossRef]

54. Spiertz, J.; Vos, J. Grain growth of wheat and its limitation by carbohydrate and nitrogen supply. In Wheat Growth and Modelling; Day, W., Atkin, R.K., Eds.; Springer: New York, NY, USA, 1985; pp. 129-141.

55. Mumtaz, M.Z.; Aslam, M.; Nasrullah, H.M.; Akhter, M.; Ali, B. Effect of various sowing dates on growth, yield and yield components of different wheat genotypes. Am. Eur. J. Agric. Environ. Sci. 2015, 15, 2230-2234.

56. Spink, J.H.; Semere, T.; Sparkes, D.T.; Whaley, J.M.; Foulkes, M.J.; Clare, R.W.; Scott, R.K. Effect of sowing date on the optimum plant density of winter wheat. Ann. Appl. Biol. 2000, 137, 179-188. [CrossRef]

57. Shahzad, M.; Din, A.; Sahi, S.T.; Ehsanullah, K.; Ahmad, M. Effect of sowing dates and seed treatment on grain yield and quality of wheat. Pakistan. J. Agric. Sci. 2007, 44, 581-583.

58. Gardner, J.S.; Hess, W.M.; Trione, E.J. Development of the young wheat spike: A SEM study of Chinese spring wheat. Am. J. Bot. 1985, 72, 548-559. [CrossRef]

59. Prevéy, J.S. Climate change: Flowering time may be shifting in surprising ways. Curr. Biol. 2020, 30, R112-R114. [CrossRef]

60. Sial, M.A.; Arain, M.A.; Mazhar, S.K.; Naqvi, H.; Dahot, M.U.; Nizamani, N.A. Yield and quality parameters of wheat genotypes as affected by sowing dates and high temperature stress. Pak. J. Bot. 2005, 37, 575-584.

61. Sial, M.A.; Dahot, M.U.; Arain, M.A.; Markhand, G.S.; Naqvi, M.H.; Laghari, K.A.; Mirbahar, A.A. Effect of water stress on yield and yield components of semi-dwarf bread wheat (Triticum aestivum L.). Pak. J. Bot. 2009, 41, 1715-1728.

62. Kilic, H.; Yagbasanlar, T. The effect of drought stress on grain yield, yield components and some quality traits of durum wheat (Triticum turgidum ssp. durum) cultivars. Not. Bot. Hort. Agrobot. Cluj. 2010, 38, 164-170. 
63. Akhter, N.; Hossainn, F.; Karim, A. Influence of calcium on water relation of two cultivars of wheat under salt stress. Int. J. Environ. 2013, 2, 1-8. [CrossRef]

64. Tuteja, N.; Singh, G.S. Plant Acclimation to Environmental Stress; Springer Science and Business Media: Berlin/Heidelberg, Germany, 2012.

65. Hasanuzzaman, M.; Hossain, M.A.; da Silva, J.A.T.; Fujita, M. Plant response and tolerance to abiotic oxidative stress: Antioxidant defense is a key factor. In Crop Stress and Its Management: Perspectives and Strategies; Venkateswarlu, B., Shanker, A., Shanker, C., Maheswari, M., Eds.; Springer: New York, NY, USA, 2012; pp. 261-315.

66. Zandalinas, S.I.; Mittler, R.; Balfagón, D.; Arbona, V.; Gómez-Cadenas, A. Plant adaptations to the combination of drought and high temperatures. Physiol. Plant. 2018, 162, 2-12. [CrossRef] [PubMed]

67. Blokhina, O.; Virolainen, E.; Fagerstedt, K.V. Antioxidants oxidative damage and oxygen deprivation stress. Ann. Bot. 2003, 91, 179-194. [CrossRef]

68. 68. Iqbal. Physiology of Wheat (Triticum aestivum L.) Accessions and the Role of Phytohormones under Water Stress. Ph.D. Thesis, Faculty of Biological Sciences, Quaid-i-Azam University, Islamabad, Pakistan, 2009; pp. 83-154.

69. Ranney, T.G.; Bassuk, N.L.; Whilow, T.H. Osmotic adjustment and solute constituents in leaves and roots of water-stressed cherry pruns tress. J. Am. Soc. Hortic. Sci. 1991, 116, 648-688.

70. Zhang, B.C.; Li, F.M.; Huang, G.B.; Cheng, Z.Y.; Zhang, Y.H. Yield performance of spring wheat improved by regulated deficit irrigation in an arid area. Agric. Water Manag. 2006, 79, 28-42. [CrossRef]

71. Maria, A.M.; Gendy, A.A.; Selim, A.H.; Abd El.-All, A.M. Response of wheat plants grown under water stress in relation to Jasmonic acid. Minufiya J. Agric. Res. 2008, 33, 1355-1375.

72. Waraich, E.A.; Ahmad, R. Physiological responses to water stress and nitrogen management in wheat (Triticum aestivum L): Evaluation of gas exchange, water relations and water use efficiency. In Proceedings of the Fourteenth International Water Technology Conference (IWTC 14), Cairo, Egypt, 2010; pp. 46-51. Available online: http:// citeseerx.ist.psu.edu/viewdoc/ download?doi=10.1.1.302.6997\&rep=rep1\&type=pdf (accessed on 24 September 2021).

73. Lawlor, D.W.; Cornic, G. Photosynthetic carbon assimilation and associated metabolism in relation to water deficit in higher plants. Plant Cell Environ. 2000, 25, 275-294. [CrossRef]

74. Blum, A. Effective use of water (EUW) and not water-use efficiency (WUE) is the target of crop yield improvement under drought stress. Field Crop. Res. 2009, 112, 119-123. [CrossRef]

75. Mahamed, M.B.; Sarobol, E.; Hordofa, E.; Kaewrueng, T.; Verawudh, S.J. Effects of soil moisture depletion at different growth stages on yield and water use efficiency of bread wheat grown in semi-arid conditions in Ethiopia. Kasetsart J. Nat. Sci. 2011, 45, 201-208.

76. Pugnaire, F.I.; Serrano, L.U.I.S.; Pardos, J.O.S.E. Constraints by water stress on plant growth. In Handbook of Plant and Crop Stress; Marcel Dekker, Inc.: New York, NY, USA, 1999; Volume 2, pp. 271-283.

77. Guendouz, A.; Semcheddine, N.; Moumeni, L.; Hafsi, M. The effect of supplementary irrigation on leaf area, specific leaf weight, grain yield and water use efficiency in durum wheat (Triticum durum desf.) cultivars. Ekin J. Crop Breed. Genet. 2016, 2, 82-89.

78. Molden, D.; Oweis, T.; Steduto, P.; Bindraban, P.; Hanjra, M.A.; Kijne, J. Improving agricultural water productivity: Between optimism and caution Agric. Water Manag. 2010, 97, 528-535. [CrossRef]

79. Fang, Y.; Du, Y.; Wang, J.; Wu, A.; Qiao, S.; Xu, B.; Zhang, S.; Siddique, K.H.M.; Chen, Y. Moderate drought stress affected root growth and grain yield in old, modern and newly released cultivars of winter wheat. Front. Plant Sci. 2017, 8, 672. [CrossRef] [PubMed]

80. Shahzad, K.; Bakht, J.; Shah, W.A.; Shafi, M.; Jabeen, N. Yield and yield components of various wheat cultivars as affected by different sowing dates. Asian J. Plant Sci. 2002, 1, 522-525. [CrossRef]

81. Hussain, M.; Farooq, M.; Shabir, G.; Khan, M.B.; Zia, A.B. Delay in planting decreases wheat productivity. Int. J. Agric. Biol. 2012, 14, 533-539.

82. Ahmad, I.; Wajid, S.A.; Ahmad, A.; Cheema, M.J.M.; Judge, J. Assessing the impact of thermo-temporal changes on the productivity of spring maize under semi-arid environment. Int. J. Agric. Biol. 2018, 20, 2203-2210.

83. Ali, M.A.; Ali, M.; Sattar, M.; Ali, L. Sowing date effect on yield of different wheat varieties. J. Agric. Res. 2010, 48, 157-162.

84. Sharma, N.P.; Sumesh, K.W.; Lohot, V.D.; Ghildiyal, M.C. High temperature effect on grain growth in wheat cultivars: An evaluation of responses. Indian J. Plant Physiol. 2006, 11, 239-245.

85. Hussain, M.; Shabir, G.; Farooq, M.; Jabran, K.; Farooq, S. Developmental and phenological responses of wheat to sowing dates. Pak. J. Agric. Sci. 2012, 49, 1-10.

86. Amini, R.A.; Alami-Milani, M.; Mohammadinasab, A.D. Effect of different irrigation treatments and mulch on water use efficiency of lentil. Int. J. Biosci. 2013, 3, 44-49.

87. Shahzad, M.W.; Razaq, M.; Hussain, A.R.J.A.D.; Yaseen, M.; Afzal, M.; Mehmood, M.K. Yield and yield components of wheat (Triticum aestivum L.) affected by aphid feeding and sowing time at Multan, Pakistan. Pak. J. Bot. 2013, 45, $2005-2011$.

88. Ali, M.H.; Hoque, M.R.; Hassan, A.A.; Khair, A. Effects of deficit irrigation on yield, water productivity and economic returns of wheat. Agric. Water Manag. 2007, 92, 151-161. [CrossRef]

89. Abid, M.; Ali, S.; Qi, L.K.; Zahoor, R.; Tian, Z.; Jiang, D.; Snider, J.L.; Dai, T. Physiological and biochemical changes during drought and recovery periods at tillering and jointing stages in wheat (Triticum aestivum L.). Sci. Rep. 2018, 8, 4615. [CrossRef] 
90. Prey, L.; Kipp, S.; Hu, Y.; Schmidhalter, U. Nitrogen use efficiency and carbon traits of high-yielding European hybrid vs. line winter wheat cultivars: Potentials and limitations. Front. Plant Sci. 2019, 9, 1988. [CrossRef]

91. Zhou, Q.; Ju, C.; Wang, Z.; Zhang, H.; Liu, L.; Yang, J.; Zhang, J. Grain yield and water use efficiency of super rice under soil water deficit and alternate wetting and drying irrigation. J. Integr. Agric. 2017, 16, 1028-1043. [CrossRef]

92. Buczek, J. Quality and productivity of hybrid wheat depending on the tillage practices. Plant Soil Environ. 2020, 66, 415-420. [CrossRef]

93. Liao, R.; Wu, W.; Hu, Y.; Xu, D.; Huang, Q.; Wang, S. Micro-irrigation strategies to improve water-use efficiency of cherry trees in Northern China. Agric. Water Manag. 2019, 221, 388-396. [CrossRef]

94. Lu, J.; Ma, L.; Hu, T.; Geng, C.; Yan, S. Deficit drip irrigation based on crop evapotranspiration and precipitation forecast improves water- use efficiency and grain yield of summer maize. J. Sci. Food Agric. 2021, in press. [CrossRef]

95. Ali, S.; Xu, Y.; Ma, X.; Ahmad, I.; Kamran, M.; Dong, Z.; Cai, T.; Jia, Q.; Ren, X.; Zhang, P.; et al. Planting patterns and deficit irrigation strategies to improve wheat production and water use efficiency under simulated rainfall conditions. Front. Plant Sci. 2017, 8, 1408. [CrossRef] [PubMed]

96. Rezaei, E.E.; Sibert, S.; Hüging, H.; Ewert, F. Climate change effect on wheat phenology depends on cultivar change. Sci. Rep. 2018, 8, 4891. [CrossRef] [PubMed]

97. Selva, C.; Riboni, M.; Baumann, U.; Würschum, T.; Whitford, R.; Tucker, M.R. Hybrid breeding in wheat: How shaping floral biology can offer new perspectives. Funct. Plant Biol. 2020, 47, 675-694. [CrossRef]

98. Bornhofen, E.; Benin, G.; Storck, L.; Woyann, L.G.; Duarte, T.; Stoco, M.G.; Marchioro, S.V. Statistical methods to study adaptability and stability of wheat genotypes. Bragantia 2017, 76, 1-10. [CrossRef]

99. Fahad, S.; Bajwa, A.A.; Nazir, U.; Anjum, S.A.; Farooq, A.; Zohaib, A.; Sadia, S.; Nasim, W.; Adkins, S.; Saud, S.; et al. Crop production under drought and heat stress: Plant responses and management options. Front. Plant Sci. 2017, 8, 1147. [CrossRef]

100. Macholdt, J.; Honermeier, B. Yield stability in winter wheat production: A survey on german farmers' and advisors' views. Agronomy 2017, 7, 45. [CrossRef]

101. Studnicki, M.; Kang, M.S.; Iwańska, M.; Oleksiak, T.; Wójcik-Gront, E.; Mądry, W. Consistency of yield ranking and adaptability patterns of winter wheat cultivars between multi-environmental trials and farmer surveys. Agronomy 2019, 9, 245. [CrossRef]

102. Sultana, M.R.; Alim, M.A.; Hossain, M.B.; Karmaker, S.; Islam, M.S. Effect of variety and weed management practices on yield and yield attributes of wheat. J. Environ. Sci. Nat. Resour. 2012, 5, 91-96. [CrossRef] 